
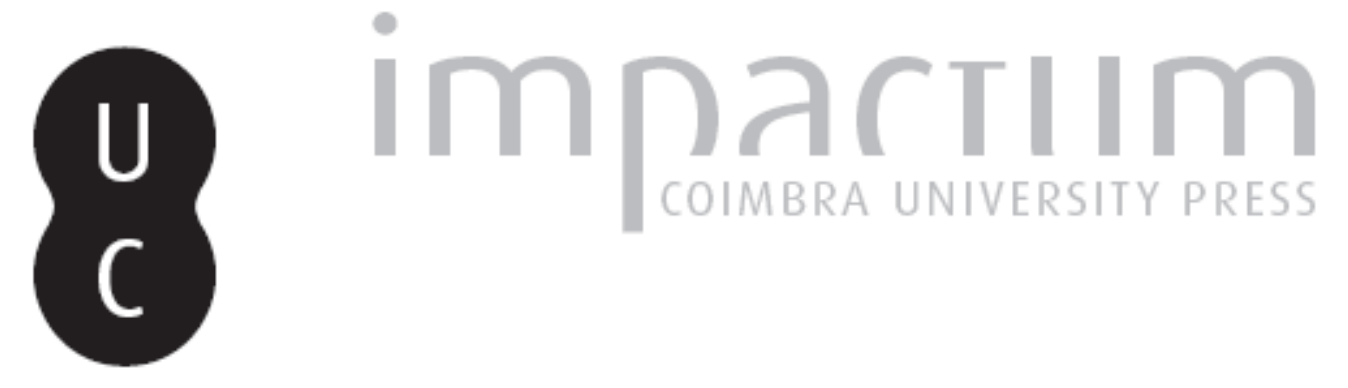

\title{
Os grafitos da muralha almóada de Alcácer do Sal
}

Autor(es): $\quad$ Cottart, Nicole Danièle; Carvalho, Antonio Rafael

Publicado por: Faculdade de Letras da Universidade de Coimbra

URL persistente:

URI:http://hdl.handle.net/10316.2/37866

DOI:

DOI:http://dx.doi.org/10.14195/1647-8657_49_10

Accessed : $\quad$ 26-Apr-2023 04:12:54

A navegação consulta e descarregamento dos títulos inseridos nas Bibliotecas Digitais UC Digitalis, UC Pombalina e UC Impactum, pressupõem a aceitação plena e sem reservas dos Termos e Condições de Uso destas Bibliotecas Digitais, disponíveis em https://digitalis.uc.pt/pt-pt/termos.

Conforme exposto nos referidos Termos e Condições de Uso, o descarregamento de títulos de acesso restrito requer uma licença válida de autorização devendo o utilizador aceder ao(s) documento(s) a partir de um endereço de IP da instituição detentora da supramencionada licença.

Ao utilizador é apenas permitido o descarregamento para uso pessoal, pelo que o emprego do(s) título(s) descarregado(s) para outro fim, designadamente comercial, carece de autorização do respetivo autor ou editor da obra.

Na medida em que todas as obras da UC Digitalis se encontram protegidas pelo Código do Direito de Autor e Direitos Conexos e demais legislação aplicável, toda a cópia, parcial ou total, deste documento, nos casos em que é legalmente admitida, deverá conter ou fazer-se acompanhar por este aviso.

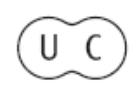


CONIMBRIGA

C)

CN N N

INSTITUTO DE ARQUEOLOGIA

VOLUME XLIX • 2010

FACULDADE DE LETRAS 
Nicole Danièle CotTART

Ressources Arabes Pour l'Archéologie UMR 5607/CNRS-Bordeaux 3

Antonio Rafael Carvalho

Gabinete de Arqueologia da Câmara Municipal Alcácer do Sal

\section{OS GRAFITOS DA MURALHA ALMÓADA}

DE ALCÁCER DO SAL

“Conimbriga” XLIX (2010) p. 183-223

Resumo: Apesar do Período Almóada em Alcácer, debaixo da jurisdição dos Banū Wazīr, ter durado entre 1191 e 1217, em contraste com uma primeira longa fase de séculos de domínio Islâmico, [entre 715 e 1160], estes 26 anos representam um manancial importante de documentação arqueológica e textual sem igual em relação aos períodos ulteriores, permitindo deste modo uma abordagem privilegiada sobre as ultimas décadas desta madīna Islâmica que se debruça nas margens do rio Sado. De fato os grafitos de cronologia Almóada identificados numa das torres da cintura fortificada da madīna Qașr al-Fatḥ insere-se neste âmbito privilegiado de análise, onde de uma maneira única podemos antever um pouco alguns aspectos íntimos da sua população, nas vésperas da conquista Portuguesa de 1217.

Este conjunto de grafitos, cuja extensão e motivos que identificamos, reputamos no al-Ġarb al-Andalus de único e coloca este painel numa posição impar e sem paralelo no al-Andalus. De modo a enquadrar o leitor da especificidade Histórica de Alcácer do Sal, estruturamos esta primeira abordagem do seguinte modo: - Começamos por tecemos uma breve introdução sobre a longa diacronia islâmica em al-Qașr até à conquista Almóada, utilizando para tal as fontes textuais medievais de autores muçulmanos e o contributo recente da Arqueologia Islâmica. A segunda parte centra-se na apresentação, análise e comentário do corpo de grafitos identificado numa das torres do castelo. Por fim, uma breve análise a uma problemática levantada por Ibn Hawqal no século $\mathrm{X}$ que tem passado desapercebida nos estudos sobre o Garb Andalusī, quando este denomina Alcácer como Qașr Banū Wardās ou Waddās, mas não Qaṣr Abī Dānis como seria de esperar.

Conimbriga, 49 (2010) 183-224 
RÉSuMÉ: Ce qu'a apporté la présence almohade à Alcácer do Sal sous le pouvoir des Banū Wazīr de 1191 à 1217, contraste avec une première longue phase de domination islamique, de 715 à 1160, dans la région. En effet, cette période qui s'étale sur vingt-six années représente un apport important d'informations archéologiques et textuelles, sans égal avec les périodes ultérieures; les données relevées permettent une approche privilégiée des évènements qui se sont produits pendant le déroulement des dernières décades de l'existence de la ville musulmane sur les bords du fleuve Sado. L'ensemble de graffites, dont nous avons identifié l'étendue est un ensemble exceptionnel dans le Ġarb al-Andalus. Ces graffites, de chronologie almohade et identifiés dans une des tours de l'enceinte fortifiée de madīna Qașr al-Fatḥ, s'insèrent dans un espace privilégié d'analyse où d'une façon unique ils permettent d'entrevoir quelques aspects de la vie de la population à la veille de la conquête portugaise de 1217.

De manière à guider le lecteur de l'article dans la spécificité historique de la ville d'Alcacer do Sal, nous avons procéder de la façon suivante: un rappel général du contexte historique du lieu, une partie plus détaillée sur la période musulmane à partir de l'analyse des sources littéraires arabes médiévales et enfin l'analyse d'un certain nombre de graffites qui nous sont apparus comme les plus spécifiques du champ glyptographique concerné. En annexe, nous publions une carte de la péninsule ibérique d'un géographe arabe du Xe siècle, Ibn Hawqal, sur laquelle il mentionne d'Alcácer mais avec une lecture différente de celle habituellement connue, ce qui relance l'hypothèse d'un autre toponyme, également utilisé à la période médiévale pour nommer le site. 


\section{OS GRAFITOS DA MURALHA ALMÓADA DE ALCÁCER DO SAL}

À primeira vista, pode parecer surpreendente que se junte uma arabista associada a um arqueólogo no âmbito da elaboração de um artigo em homenagem ao professor Robert Etienne. De fato, se o programa de pesquisa sobre os Ressources Arabes Pour l'Archéologie existe há vários anos em Bordéus, no Instituto Ausonius ${ }^{1}$, foi graças a ele.

Sem querer repetir as razões históricas que me levaram a deixar o meu laboratório de Paris ${ }^{2}$ onde eu me ocupava de manuscritos árabes, sobre prosopografia do Islão medieval e de islamólogia ${ }^{3}$, desejo esclarecer que foi ao seguir os desejos de professor Robert Etienne, que me mudei e instalei-me neste instituto, na qualidade de arabista, para implementar um programa voltado para este tema. Este programa, baseia-se na análise das fontes literárias árabes, em manuscritos e documentação impressa, com o objectivo de prestar assistência aos arqueólogos que trabalham, em particular na Península Ibérica. Foi então que, com toda a naturalidade

${ }^{1}$ UMR 5607 du CNRS-Université Bordeaux 3

${ }^{2}$ Institut de Recherche et d'Histoire des Textes (IRHT), Section arabe, Paris/ UPR841 du CNRS

3 Cottart, N. D., «Un manuscrit biographique conservé à Meshed» in Cahiers d'Onomastique arabe 1981, Paris, 1982, pp 115-118; idem, éditeur de Georges Vajda, La transmission du savoir en Islam, VIIe-XVIIIe s., Londres,1983; idem, Mise à jour du traitement informatique des données biographiques de l'Onomasticon Arabicum, CNRS/IRHT, Paris, 1986; idem, «Le livre de Kalila et Dimna» in Le livre au Moyen-Âge sous la direction de Jean Glénisson, pp 144-145, Paris,1988; idem, participation à la base de données de l'IRHT-CNRS Onomasticon Arabicum-prosopographie de l'Islam médiéval, en particulier à la mise en ordinateur des données du Šadarât al-dahab d'Ibn al-'Imād, du Šadarāt an-nūr az-zakiyya de Muhammad Maḩlūf et d'al-Muqtaḍab min kitāb tuhfat al-qādim li-ibn al-Abbār, Paris, 2009, (voir le site Aedilis de l'IRHT, mis à jour en 2010).

Conimbriga, 49 (2010) 183-224 
que Françoise Mayet e o professor Robert Etienne me propuseram enviar-me a Portugal a fim de examinar algumas inscrições em árabe, o que aconteceu no Outono de 2004. Quanto às minhas pesquisas e perspectivas, não são as inscrições lapidares oficiais as que atraíram a minha atenção, a maioria das quais já foram estudadas por colegas epigrafistas de árabe, portugueses e espanhóis ${ }^{4}$, mas sim as inscrições menos formais e que existem em maior numero, aquelas que figuram sobre os objectos exumados a partir de escavações arqueológicas de níveis muçulmanos sob a forma de grafitos. Estas marcas de propriedade ou de destino, fórmulas piedosas ou mágicas, revelam-se mais preciosas porque a maioria deles nunca foram identificadas. Agora, o suporte do objecto arqueológico examinado não se resume somente ao manuscrito, objecto somente reservado à elite, mas sobretudo o objecto comum, aquele que foi utilizado na vida quotidiana, pelos próprios indivíduos, pelos mais pobres, e sobre os quais tinham a possibilidade de deixar um traço, ou até mesmo uma impressão digital.

Quando em Maio de 2009, António Rafael Carvalho me mostrou um fragmento de cerâmica com uma inscrição, fui então convidada, a fim de ajudar na leitura em árabe, de uns grafitos que ele tinha descoberto há alguns anos na Torre Norte da muralha almóada de Alcácer do Sal, o qual aceitei com entusiasmo e curiosidade. Ao pé da torre, os nossos esforços de atenção e observação em conjunto, permitiram não só identificar alguns traços e linhas como se oferecia aos nossos olhos um verdadeiro campo gliptológico, comportando diferentes tipos de desenhos: barcos, peixes, símbolos e de palavras em árabe. A magnitude desta descoberta para o domínio da arqueologia islâmica em Portugal é considerável. De fato, segundo os dados por nós conhecidos, não existe outro sítio no Ġarb al-Andalus, que inclui tanta informação do período muçulmano sobre uma área desta natureza (Fig. 1).

É portanto, uma primeira análise a partir dessa descoberta que optámos por apresentar no âmbito deste volume de homenagem, tendo em conta a importância da informação, o estudo dos grafitos ainda está

4 Martínez Núñez, Ma. A., «Al-Andalus y la documentación epigráfica», in Fontes da História de al-Andalus e do Gharb, éditeur A. Sidarus, pp. 89-115, Lisbonne,2000; Barceló Torres, C. et Labarta, A., «Dos inscriptiónes arabes halladas en Alcácer do Sal», in Setubal Arqueológica, 8, Setubal,1987, pp. 265-70; idem, «Inscripciónes árabes portuguésas: situación actual», in Al-Qanțara, VIII, Madrid, 1987, pp. 395.

Conimbriga, 49 (2010) 183-224 
em curso ${ }^{5}$. Esperamos sinceramente que através desta descoberta e o estudo que nos propusemos comunicar, possamos contribuir, mesmo que modestamente, para fazer perdurar a obra do professor Robert Etienne em Portugal, para além da noção de tempo e encorajamento que sempre conseguiu apresentar neste programa de investigação a fim de superar as dificuldades e ainda assim prosseguir com pugnacidade.

Para um melhor enquadramento da problemática que nos interessa, julgamos importante elaborar uma síntese histórica geral de Alcácer do Sal e da região envolvente, assim como da documentação arqueológica aqui exumada, antes de desenvolver uma abordagem mais detalhada ao contexto Tardo Islâmico que nos interessa para estudar de forma adequada este conjunto grafitado.

Alcácer do $\mathrm{Sal}^{6}$ é uma cidade situada a $60 \mathrm{~km}$, em linha recta, para sul de Lisboa, localizada na margem direita do rio Sado, inserida no Alentejo Litoral (Fig. 2). Os vestígios arqueológicos descobertos na sua área urbana (castelo, porto e espaços peri-urbano), remontam ao Período Neolítico; quando a região terá sido habitada por um grupo de população indo-europeia pré-ibérica. Os vestígios seguintes revelaram em seguida a passagem e presença mais ou menos longa de fenícios, romanos e de outros povos da Bacia Mediterrânica, de África (Magrebe e Saariana) árabes e berberes. ${ }^{7}$ A actividade portuária de Alcácer terá começado na Idade do Ferro, em meados do I Milénio antes de Cristo, graças ao desenvolvimento económico iniciado pelos Fenícios na região, nomeadamente no sítio do Abul. ${ }^{8}$ Nessa época, a península de Tróia não existia e comportava-se como uma ilha no amplo paleoestuário do Sado, aberto ao oceano Atlântico.

No Período Romano, a cidade de Alcácer foi sede de uma civitas e recebeu o nome de Salacia Urbs Imperatoria. Durante o Alto Império,

5 Uma parte deste trabalho foi objecto de uma apresentação no quadro do XVIIe Colloque International de Glyptographie que teve lugar em Cracóvia, de 4 a 10 de Julho de 2010

6 Coordenadas geográficas de Alcácer do Sal: 38²2’23.54” N 8³1’32.33” O, Google Earth, 2010.

7 De Planhol, X., Les fondements géographiques de l'histoire de l'Islam, Paris, 1968; Etienne, R. et Mayet, Fr. édit. Itinéraires lusitaniens. Trente années de collaboration archéologique luso-française, Paris, 1997.

8 Mayet, Fr. et Tavares da Silva, C., avec la collaboration de Makaroun, Y., L'établissement phénicien d'Abul (Portugal), Comptoir et sanctuaire, Paris, 2000; idem, L'atelier d'amphores d'Abul (Portugal), Paris, 2002

Conimbriga, 49 (2010) 183-224 
Salacia era um dos portos marítimos mais importantes da província romana da Lusitânia graças à sua localização excepcional junto à foz do Sado, no encontro entre o oceano e a via fluvial. ${ }^{9}$ Esta posição geográfica e estratégica terá permitido efectivamente um fluxo rápido de produtos agrícolas do interior, como o trigo, o azeite e o vinho, bem como a exportação de produtos industriais derivados da produção do sal e da salga de peixe ${ }^{10}$, para outros lugares do Mediterrâneo ocupados por Roma.

A partir do século III depois de Cristo, a actividade portuária de Alcácer sofre um declínio em benefício da expansão comercial de Lisboa ${ }^{11}$. È o fim da importância económica do porto assim como da cidade. O declínio do sítio a partir da Antiguidade Tardia será interrompido após a chegada dos muçulmanos a esta região, cinco séculos mais tarde.

Diante do silêncio das fontes textuais da Antiguidade Clássica, o estudo do contexto histórico de Alcácer do Sal em âmbito romano só pode ser feita através da análise da documentação arqueológica. É de notar que quase toda a investigação arqueológica efectuada até ao momento foi centrada na área da fortaleza, em detrimento da área portuária que se estende ao longo do Sado. Neste contexto, a documentação arqueológica exumada no recinto fortificado mostra efectivamente um aumento de cultura documental no Alto Império, seguindo-se um brusco decréscimo na Antiguidade Tardia ${ }^{12}$ e Período Visigótico. No decurso desta ultima fase, existem apenas alguns fragmentos de cerâmicas e pedra que anunciam uma fugaz presença humana neste espaço.

Alguns investigadores têm argumentado que a cidade de Salacia teria desaparecido após o século III depois de Cristo, ignorando completamente a documentação arqueológica que poderia eventualmente existir na zona portuária, ao longo do rio Sado. Defendia-se que a reocupação do local

9 ibid. pp11-13.

10 Etienne, R. et Mayet, FR., Le vin lusitanien, Paris, 2000; idem, Salaisons et sauces de poissons hispaniques, Paris, 2002; idem, L'huile hispanique, Paris, 2004.

11 Fabião, C., «Cetarias, Ânforas e Sal: A Exploração de Recursos marinhos na Lusitânia» em Estudos Arqueologicos de Oeiras, n 17, Oeiras, 2009, pp. 555-594.

12 Justino Maciel, M., Antiguidade Tardia e Paleocristianismo em Portugal, Lisboa, 1996; Carvalho, A.R., "A Antiguidade Tardia e a Islamização na Costa Sesimbrense» in O Tempo do Risco - Carta Arqueológica de Sesimbra, Coordenação Manuel Calado e Luís Jorge Gonçalves, Sesimbra, 2009, pp. 172-191.

Conimbriga, 49 (2010) 183-224 
teria ocorrido após a chegada dos Banū Dānis na segunda metade do século IX, numa fase avançada do emirato Omieda. ${ }^{13}$

A avaliação da rara documentação arqueológica encontrada dentro do espaço fortificado assim como os novos elementos encontrados nas escavações ao longo do Sado, vieram renovar a informação documental sobre a diacronia de Alcácer depois do século segundo depois de Cristo, até à chegada dos Banū Dānis em 877 e da construção da alcáçova, ${ }^{14}$ do árabe al-qașaba, palácio fortaleza e/ou parte central de uma aglomerado. Estes elementos estabelecem assim que a passagem da população urbana do alto do sítio, para as margens do Sado, contribuíram para o empobrecimento do primeiro. Por outro lado, a existência de cerâmicas romanas do Baixo-império e de importações de Sigillatas africanas da Tunísia, com cronologias tardias dos séculos V a VI, atestam a actividade do porto de Alcácer; atestando a presença humana que se mantêm, mesmo que pobre, neste espaço, até à chegada dos primeiros representantes do poder islâmico instalado em Bāğa (Beja), em meados da primeira metade do século VIII. ${ }^{15}$

O interesse inicial baixo manifestado pelo poder islâmico no âmbito das actividades portuárias no século VIII, terá ajudado a manter uma população autóctone residual em Alcácer. ${ }^{16}$ As fontes mencionam que se tratava de um qașr (palácio), mas sem o estatuto de madìna (cidade) estando sujeita a Bāğa (Beja). ${ }^{17}$

Os ataques dos Vikings sobre esta parte da costa portuguesa começaram em 844. Eles contribuíram para o abandono de várias aldeias junto à costa incapazes de se defenderem, ${ }^{18}$ caso de Setúbal, Ribeira

13 Tavares da Silva, C. et alii., «Escavações arqueológicas no Castelo de Alcácer do Sal (campanha de 1979)», in Setúbal Arqueológica, 1980, vol. 6-7, Setúbal, 1980-81, pp. 114-218; Carvalho, A.R. "Al-Qașr: Alcácer do Sal Islâmica», Roteiro - Cripta arqueológica do Castelo de Alcácer do Sal, Lisboa, 2007, pp. 43-56.

14 loc.cit. Carvalho, A.R.; Deverdun, G., «al-Kașaba», Encyclopédie de l'Islam 2, vol. IV, Leyde, pp. 684-86; Lévi-Provençal, E., Histoire de l'Espagne musulmane, 3e éd., Paris, 1999; Miquel, A., Al-Muqadassī, Damas, 1963.

15 loc.cit. Carvalho, A.R.

16 loc.cit. Carvalho A.R.

17 Ibn al-Abbār, Kitāb at-takmila li-kitāb aṣ-șila, (2 vol), éd. F. Codera, Madrid, 1888-1889.

18 Yāqūt al-Hamawī, Mu 'ğam al-buldān, 2e éd., Beyrouth, 1995, 7 vols

Conimbriga, 49 (2010) 183-224 
de Sesimbra e Sines, ${ }^{19}$ contribuindo deste modo para a valorização dos locais situados em pontos altos que na altura teriam sido objecto de ocupação pelo poder islâmico, como Palmela, Sesimbra ou Alcácer do Sal. Durante este período de recuperação estratégica, Alcácer oferecia uma estrutura castral que chamou a atenção e interesse dos Banū Dānis para o fim do século IX. Esta posição, embora afastada do mar, possui excelentes instalações portuárias nas margens do Sado, agora chamado de Nahr Šatūbar (al-Idrīsī), depois Nahr (a)bū Dānis (Abū l-Fidā). De facto, vários cronistas muçulmanos relatam que os Banū Dānis terão transformado esta praça-forte em madīna, cidade islâmica. A escavação arqueológica efectuada no subsolo do museu municipal de Alcácer do Sal, situado junto ao rio, indicam a existência de um complexo portuário com estruturas de casas, poços, silos que remontam à Idade do Ferro e perduram até aos nossos dias ${ }^{20}$. As provas arqueológicas importantes já foram recolhidas e correspondem a cerâmicas datadas da época romana - Alto e Baixo Império, do Período Visigótico, Período Islâmico; Emirato, Califal, reinos de Taifas e Fase Magrebina (Almorávidas e provavelmente Almóada) - até à Reconquista Cristã.

A documentação arqueológica atesta a existência de dois pólos económicos na cidade: A praça-forte/acrópole e o porto. Assim, ao longo da sua história, depois da Idade do Ferro até ao último século, o coração económico de Alcácer foi o seu porto, associado à construção naval, à exploração do sal do Sado e aos produtos derivados da pesca. Estes elementos são fundamentais para uma boa compreensão da história e evolução do tecido urbano de Alcácer do Sal ${ }^{21} \mathrm{~A}$ importância notória do porto jogou igualmente um papel importante na vida política e cultural do sítio, transformando-se no centro activo do Baixo Sado nesta região, ao longo dos séculos.

19 Ferreiro Alemparte, J., Arribadas de Normandos y Cruzados a las Costas de la Península Ibérica, Madrid, 1999.

20 Ferreira, M Aires. et Cabrita, A. Catarina., Escavações na Igreja do Espírito Santo-Alcácer do Sal, $3^{\circ}$ Encontro de História do Alentejo Litoral, nos 100 anos da Republica (Sines-Grándola), (apresentação oral - Sines 2010).

21 Carvalho, A.R. et alii., Al-QAȘR, Alcácer do Sal Islâmica: Arqueologia e História de uma Medina do Garb al-Andalus (séculos VIII-XIII), Alcácer do Sal, 2008; Picard, Ch., Le Portugal Musulman (VIII-XIII siécles): L'Occident d'al-Andalus sous domination islamique, Paris, 2000.

Conimbriga, 49 (2010) 183-224 


\section{O contexto histórico específico muçulmano}

Entre os geógrafos e historiadores árabes ${ }^{22}$ os mais representativos para a história do ocidente muçulmano que descreveram o sítio de Alcácer, podemos citar os seguintes:

- Ibn Ḥawqal, Abū 1-Qāsim b. 'Alī an-Naşībī, nasceu em Nisibe na Alta Mesopotâmia em 331/943; perde-se o rasto após este ter efectuado uma viagem para a Sicília em 362/973;

- Ibn Ḥazm, Abū Marwān 'Alī b. Aḥmad b. Sa'īid, nasceu em Córdoba em 384/994 e morreu em 456/1064;

- Ibn Ḥayyān, Abū Marwān Ḥayyān b. Ḥalaf b. Ḥusayn b. Ḥayyān, nasceu em Córdoba, em 377/987-8 e morreu em 469/1076;

- Yāqūt Abū 'Abd Allāh b. 'Abd Allāh al-Hamawī, nasceu na Ásia Menor em 575/1179 e morreu em Alepo em 626/1129;

- al-Idrīsī Abū 'Abd Allāh Muḥammad b. 'Abd Allāh b. Idrīs al-Šarīf, nasceu em Ceuta em 493/1099 e morreu na Sicília, em 560/1165-1166;

- Ibn Al-Abbār Abū 'Abd Allāh Muḥammad b. 'Abd Allāh, nasceu em 595/1199 em Valencia e morreu em 658/1260;

- al-Ḥimyarī Abū 'Abd Allāh Muhammad b. 'Abd al-Mun'im, viveu em Marrocos no século XIII;

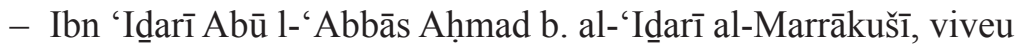
durante a segunda metade do século VII/XIII até ao VIII/XIV;

- Ibn Abī Zar' Abū l-'Abbās Aḥmad al-Fāsī, morreu em Fez, entre 710 e 720/1310- 20;

- al-Ayyūbī Abū l-Fidā' Ismā‘îl b. 'Alī, nasceu em Damasco, em 672/1273 e morreu em Hama em 734/1334

Eles chamam a cidade segundo os seguintes nomes em árabe: Qașr Bāja, madīnat al-Qașr, Qașr Abī Dānis, Qașr Banī Waddās ou Banī

22 Listas parciais em in Sidarus, A. e Rei, A., «Lisboa e seu termo segundo os geógrafos árabes», in Arqueologia Medieval 7, Mertola-Porto, 2001, pp. 37-72; Rei, A., «O Gharb al- Andalus em dois geografos arabes do seculo VII/XIII: Yāqūt al-Hamāwī e Ibn Sa‘īd al- Maghribī», in Medievalista, n 1, pp. 1-9, Lisboa, 2005; Garciá Sanjuan, A., «La caracterizacion geografica del Garb al-Andalus en las fuentes arabes medievales», in Medievalista, $\mathrm{n}^{\circ}$ 6, Lisboa, 2009, pp. 2-11. 
Warrās (ver o mapa no final do artigo e o seu comentário), al-Qașr ou Qașr Būdānis e caracterizam-na da seguinte forma:

“... Cidade do al-Andalus, localizada a Ocidente, pertence à zona rural de Beja (Bāğa), a dois dias de Évora (Yabūra), na "Baia do Âmbar" (al-Ğūn al-'anbarī), o âmbar ('anbar) existe nas suas cotas (sawāhil), e entre ela e o oceano há vinte milhas e que entre ela e Silves (Šilb) há quatro dias [de caminho] (marāhili)...Ela é próxima da praça-forte (al-qașr) com a qual existem ligações; é uma cidade fortificada (madīna hașiña), [de tamanho] médio (mutawassița), sobre a margem (diffa) de um grande rio (nahr kabīr), o rio Sado (Šatūbar) onde circulam muitos barcos (sufun) e embarcações de passageiros (marākib/sufun as-safariyya)... Por causa dos partidários da Cruz ('ibād aș-șalīb), houve um combate celebre com os muçulmanos... aconteceu no limite das fronteiras do Islão (tugiūr al-Islām) neste sector..."

A presença muçulmana em Alcácer começa pouco depois da conquista árabe da península ibérica em 711 da era cristã. Durante quase um século, de meados do século VIII até à primeira metade do século IX, precisamente em 844, o local limita-se a ter um papel subalterno, tratando-se de uma estrutura fortificada, dependente da cidade de Bāğa (Beja) denominada al-Qașr, (a fortaleza) ou Qașr Bāğa; para os períodos emirais e califais do al-Andalus, ver E. Lévi-Provençal e M. Meouak ${ }^{23}$.

Após os primeiros ataques lançados pelos Vikings sobre o litoral lusitano, o poder emiral de Córdova escolhe o sítio de Alcácer como base militar para a vigilância e segurança da costa ocidental, incluindo o litoral da Arrábida, o Alentejo Litoral e a Costa Vicentina. Os Banū Dānis, expulsos da cidade de Coimbra, em 262 da Hégida, por volta de 875-876 d. Cristo, chegam pouco depois a este local onde se instalam, preferindo Alcácer em detrimento de Lisboa. Eles transformam o sitio na sede regional do seu poder, onde mantêm um ribāt, ${ }^{24}$, forte misto religioso e militar no contexto da ğihäd (guerra santa) no interior da

23 Lévi-Provençal, E., Histoire de l'Espagne musulmane, 3e éd. Paris, 1999; Meouak, M., Pouvoir souverain, administration centrale et élites politiques dans l'Espagne umayyade (IIe-IVe/VIIIe-Xe siècles), Helsinki, 1999.

24 Rabbat, N., «Ribāț, Encyclopédie de l'Islam 2, pp 418-492, (pour l'analyse $\mathrm{du}$ terme ribāt dans les sources arabes) voir Cl. Cahen, L'Islam des origines au début de l'empire ottoman, Paris, 1970; Azuar Ruiz, R. et alii., Fouilles de la Rabita de Guardamar I-El ribāt califal, Excavaciones y estudios (1984-1992), Collection de la

Conimbriga, 49 (2010) 183-224 
madīna (cidade). A partir desta data, o local toma o nome de Qaṣr Abī Dānis.

No século X, durante o período califal, Qașr Abī Dānis vai ser escolhida para sede da base naval do estado islâmico no Garb al-Andalus. Em 997, este porto é escolhido por Ibn Abī 'Amir al-Manșūr para enviar uma armada de reforço para atacar a Galiza. Segundo Maurice Lombard: "Au Xe et au XIe siècles des expéditions musulmanes partent contre la Galice de l'arsenal d'al-Sașr (Alcácer do Sal), la grande création atlantique du califat de Cordoue» ${ }^{25}$.

No decurso dos séculos seguintes, durante o reino dos primeiros mulūk at-țawà 'if (reis de Taifas), é possível que a cidade continue a jogar um rolo activo no tráfico marítimo, contudo toda a região é envolvida nas guerras entre os principais principados muçulmanos, nomeadamente os de Bațalyaws/Badajoz e o de Išbīliya/Sévilha ${ }^{26}$.

Em meados do século XI, os "monjes soldados" ou Almorávidas, al- Murābițūn, ${ }^{27}$ lançam do Mag̉rib, no actual Marrocos, a ğihād, a guerra santa, contra os «maus muçulmanos» do al-Andalus sob a orientação do propagandista $m \bar{a} l i k \bar{l}{ }^{28}$ Ibn Yāsīn. A região é deste modo ligada e depois anexada ao emirato norte africano. Qașr Abī Dānis que seria o porto mais importante da taifa de Bațalyaws / Badajoz, vai ser escolhida para acolher a armada do Ṭag̉r al-ğalāliqa (a Marca Ocidental) do al-Andalus. A sua posição estratégica terá sido uma das razões para

Casa de Velazquez, vol. 85, Madrid 2004; Padilla, L., «El Ribat: institución espiritual y militar», Arqueologia Medieval.com, 2006.

25 Lombard, M., Espaces et réseaux du haut moyen âge, Paris-La Haye, 1972, pp. 161-162.

26 Lévi-Provençal, E., «Les 'Mémoires' de 'Abd Allāh, dernier roi ziride de Grenade», in Al-Andalus, vol III, Madrid, 1935, pp. 233-344; Terrasse, H., «Caractères généraux des émirats espagnols du XIe siècle» in Revue de l'Occident musulman et de la Méditerranée, n², Aix en Provence, 1966, pp. 189-198; Wasserstein, D., The Rise and Fall of the Party-Kings, Politics and Society in Islamic Spain 1002-1086, Princeton, 1983.

27 Lagardère, V., Les Almoravides jusqu'au règne de Yūsuf B. Tāšfin (1039-1106), Paris, 1989; idem, Les Almoravides: Le Djihad Andalou (1106-1143), Paris, 1998; Carvalho, A.R., «Al-Qasr/Alcácer do Sal em Contexto Almorávida (1094-1146): De Medina-Marsa Aftássida a Medīna-Ḥạ̄ira do Taghr al-Adna», I Encontro de Arqueologia e História de Alcácer do Sal. Reunião Cientifica efectuada em homenagem a João Carlos Faria, Alcácer do Sal, 2008, (prelo).

28 Cottart, N. D., «Mālikiyya», Encyclopédie de l’Islam 2, vol. VI, pp. 263-268.

Conimbriga, 49 (2010) 183-224 
esta escolha; devido á ligação directa do seu porto com o oceano, $b a h r$ $a z$-zulumāt, tornando possível e fácil os contactos com Išbīliya/Sevilha e esta com o Magreb para a recepção de reforços militares. Teremos que esperar pela queda do emirato Almorávida, altura em que Alcácer se torna de novo num reino independente, desta vez tendo à sua frente 'Alī ibn al-Wahībī, um aliado do primeiro rei de Portugal, D. Afonso Henriques, dez anos após a conquista de Lisboa por ele, em 1147.

Em 1160, Alcácer é por sua vez conquistada pela primeira vez por D. Afonso Henriques, antes que a conquista almóada volte a dominar militarmente a cidade e a região. $O$ primeiro governo cristão em Alcácer vai durar 31 anos, de 1160 a $1191^{29}$. Foi nesse ano de 1191 que o califa almóada Ya'qūb al-Manșūr conquista a cidade e recupera o território muçulmano até ao Tejo, frente a Lisboa; Alcácer recebe o nome de Qașr al-Fath, «a fortaleza da conquista» [Fig. 3].

Após a conquista almóada, o primeiro governador de Qașr al-Fatḥ, Muhammād ibn Sidrāğ ibn Wazīr morre durante a Batalha de Las Navas de Tolosa, em 1212. Sucede-lhe o seu filho 'Abd Allāh ibn Wazīr, que governou até à conquista da cidade pelos Portugueses em 1217. A tradição de deixar no poder de uma região de fronteira tão estratégica, elementos da mesma família, nomeadamente os Banū Wazīr, foi pouco usual no decurso do califado almóada. Com efeito, em 1203 o califa an-Nāṣir muda os governadores de Išbīliya/Sevilha, Šilb/Silves, Bațalyaws/Badajoz e o comando naval de Sabta/Ceuta, mas ele não alterou o Governo de Qașr al-Fatḥ. Porquê este favor concedido aos Banū Wazīr? Será que estamos perante algum tipo de autonomia concedida a uma família que governa uma área sensível, como é o caso do tagir al-Ġarb, a Marca Ocidental do califado Almóada?

O domínio almóada dura vinte e seis anos, de 1191 a 1217; ele corresponde ao período durante o qual foram gravados os grafitos que apresentamos neste trabalho, encontrado numa das torres da cintura fortificada, voltada a norte.

Após a reconquista cristã, a população muçulmana é obrigada a abandonar o recinto protegido das muralhas e instalar-se no arrabalde

29 Carvalho, A.R., «Alcácer do Sal entre 1191 E 1217: Os dias em que Qasr al-Fath foi sede do Império Almóada», Neptuno, n 6, 2005, pp. 12-13; Cressier, P., Fierro, M. et Molina, L., Los Almohades: problemas y perspectivas, Madrid, 2005.

Conimbriga, 49 (2010) 183-224 
de Alcácer (actualmente conhecido como bairro dos açougues) ${ }^{30}$ Vai ser a Ordem de Santiago quem vai investir na recuperação militar do castelo, procedendo a algumas reparações (não recuperando na totalidade o sistema defensivo almóada) e que vai escolher esta praça-forte para a sede do ramo português da Ordem no Reino de Portugal. Os mudejares/ muçulmanos que ficaram nos reinos cristãos, irão ser divididos entre as Ordens militares e os soberanos. É este o destino da comunidade islâmica que decide ficar e que irá manter-se desde 1218 até meados de 1480, ano em que perdemos o seu rasto documental, em consequência do declínio demográfico, conversões ao cristianismo e casamentos mistos sequentes, fundindo-se gradualmente na sociedade portuguesa da época.

Para concluir esta parte, para o período que nos interessa, os grafitos apresentados actualmente, atestam a presença de muçulmanos em Qașr al-Fatḥ nos séculos XII e XIII. Os cronistas cristãos e muçulmanos são unânimes sobre a importância naval do lugar desde o início até ao final do califado almóada, se bem que por razões diferentes, na perspectiva cristã essa actividade resumia-se a acções de pilhagem, enquanto do lado islâmico, ela era sentida como ğihād/guerra santa ${ }^{31}$. Na Historia Compostellana $^{32}$ (texto tradicionalmente atribuído a Munio (ou Nuno) Alfonso, bispo de Mondoñedo, Hugo, bispo do Porto, e Giraldus (ou Girardus), cânone de Santiago de Compostela no século XII, é mencionado a propósito da expedição liderada pelos Banū Maymūn em 1113, que as pessoas de Alcácer do Sal e outros Sarracenos que habitavam junto ao mar, tinham o habito de construir navios e armá-los com tropas que eram utilizadas para devastar as costas e as populações que nela habitavam, desde Coimbra, no reino de Portugal, até aos Pirenéus.

Agora, graças à descoberta dos grafitos, a documentação arqueológica de âmbito muçulmana obtida no terreno, vem ajudar na análise das fontes documentais escritas. Ela confirma, por um lado, a importância do papel da actividade económica de Alcácer e das relações comerciais

30 Carvalho, A.R., «Alcácer do Sal no Final do Período Islâmico (Séculos XII-XIII): Novos Elementos sobre a $1^{\text {a }}$ Conquista Portuguesa», Colecção Digital - Elementos para a História do Município de Alcácer do Sal, nº 1, 2008.

31 Picard, Ch., L'océan Atlantique musulman de la conquête árabe à la l'époque almohade, Paris 1997; Carvalho, A. R., «A actividade marítima de Qașr al-Fatḥ/Alcácer do Sal, no Alentejo litoral (1191-1217): pirataria ou Yihad marítima contra o reino de Portugal?», in Actas do II Encontro de Historia do Alentejo Litoral, Sines, p. 81-98, 2010 .

32 Falque, E., éditeur, Turnhout, 1988.

Conimbriga, 49 (2010) 183-224 
estabelecidas com o Mediterrâneo Ocidental e Norte da África por uma parte, testemunhando igualmente o desenvolvimento da sua actividade cultural e religiosa.

\section{Os Grafitos $^{33}$}

Estamos perante um conjunto de elementos descobertos em 2003 e 2009. Eles provêm da descoberta efectuada em duas fases ao longo de uma parede de uma das torres da área fortificada de Alcácer do Sal, a Torre 13, (orientada norte e com cronologia almóada).

A primeira descoberta foi feita em 2003 por um de nós, arqueólogo. Inicialmente tínhamos identificado linhas que pareciam corresponder a vestígios de palavras em árabe, enquanto outras linhas (a quilha e o início da ponte) de um barco em um fundo de ondas altamente estilizados, de tipo dente de serra, não nos permitiu na altura identificar seguramente o que seria. Em Maio de 2009, para confirmar o que previamente tínhamos identificado ulteriormente, procedemos a um exame cuidadoso deste espaço gliptológico. Deparamo-nos com novos conjuntos de diagramas e inscrições, nomeadamente; dois tipos de barcos, peixes, nova caligrafia árabe - palavras e nomes próprios - e símbolos. Vários temas foram identificados, nomeadamente alguns que não constam da recente catalogação e classificação definida por André Bazzana ${ }^{34}$, mas esta nomenclatura permanece em aberto, conforme reconhece o autor. Face a este panorama inesperado que revelou um conjunto impar desta natureza, decidimos trabalhar juntos, um arqueólogo, com uma arabista, para combinar as duas especialidades, permitindo deste modo

33 Um esclarecimento sobre o emprego do termo grafito que usamos e não o de grafitto/graffiti reconhecido por dicionários, incluindo o Le Robert, o Larousse ou o de Quillet: "nom italien donné par les archéologues aux inscriptions ou dessins faits sur les murs antiques, ou inscriptions ou dessin trace sur les murailles, les monuments dês cites antiques...." Existe um termo que se aproxima da lingua francesa, o grafito, igualmente utilizado na lingua portuguesa e pelos arqueólogos, nomeadamente pelo professor Robert Etienne. É neste âmbito que reside a nossa preferencia.

34 Bazzana, A., «Les graffiti de bateaux dans al-Andalus et au Maghreb al-Aqsâ», in Les Cahiers de l'Urbanisme, Mélanges d'archéologie médiévale, Liber amicorum en hommage à André Matthys, Bruxelles, 2006, pp. 16-34; Souto, J., 1988, «Marcas de cantero, graffiti y 'signos magicos' en el Mundo Islamico: panoramica general», in Actas des V Coloquio International de Glyptographie, I, Pontevedra, pp. 463-486.

Conimbriga, 49 (2010) 183-224 
uma análise pluridisciplinar sobre todos os grafitos identificados, o seu registo, a sua leitura e análise contextual [Fig. 4].

É difícil obter informação que nos permita datar os grafitos. O que podemos garantir é que estes foram gravados pouco depois de 1191, ou até 1217, numa torre de cronologia almóada, que por sua vez foi erguida sobre uma base de fundação romana. É possível que o sistema defensivo que sobreviveu até hoje contenha algumas secções de parede anteriores, nomeadamente de cronologia almorávide. ${ }^{35}$

Outra hipótese que se pode colocar é se os grafitos poderiam ter sido executados pouco depois da conquista portuguesa de 1217, por elementos muçulmanos da comunidade mujedar aqui residente? Sabemos que após essa data, a população muçulmana foi obrigada a deixar a medina, revertendo este espaço para a população cristã, e instala-se no arrabal sob a dupla protecção do rei e da Ordem de Santiago. ${ }^{36}$

De facto fica no ar uma questão. Fará sentido colocar furtivamente inscrições em árabe, para que todos possam ver, numa torre que agora faz parte do sistema de defesa da "cidade cristâ"? Dado que a população é agora cristã e as novas autoridades desconheciam o árabe, será que estes grafitos julgaram um papel de cripto-islamismo cujo alcance desconhecemos? Propaganda para manter viva os referenciais culturais islâmicas (!) Essa hipótese parece improvável, dado que uma das principais preocupações do poder cristão era apagar todos os vestígios da presença muçulmana nos territórios reconquistados. De facto, temos relatos que testemunham os rituais de purificação no acto de transformação de uma mesquita em igreja cristã. Logo, a suspeita de que existissem grafitos com caracteres em árabe, seria motivo de rápida destruição.

A análise em curso de uma linha de registo oficial, raspada, mas aonde perduram alguns traços diluídos, fantasmas, permite confirmar que a datação destes grafitos foram efectuados em época islâmica, mas por outro lado, permite revelar intenções de propaganda com relação ao seu registo. De fato, é improvável que esta inscrição, inscrita no estuque a uma altura difícil de alcançar por um homem, figure nessa posição unicamente apenas para o propósito exclusivo de um indivíduo pode

35 Carvalho, A.R. loc. cit. p. 56.

36 loc. cit. p. 83; Boissellier, S., «Réflexions sur l'idéologie portugaise de la reconquête, XIIe- XIVe siècles», in Mélanges de la Casa Velazquez, Tome XXX-1, Madrid, 1994.

Conimbriga, 49 (2010) 183-224 
deixar uma marca pessoal. Defendemos que se trata de uma inscrição de carácter "oficial".

O lado norte da torre 13 [Fig. 5], tem uma altura de seis metros, possuindo uma arquitectura típica das estruturas construídas na região por iniciativa do califa Ya'qūb al-Manșūr (morreu em 1199) e específicos da região Ocidental do andaluz. ${ }^{37} \mathrm{O}$ material usado corresponde a uma "argamassa militar", como poderemos constatar noutras áreas fortificadas conhecidas de, Silves, Badajoz, Cáceres, Niebla, Albacar e Reina. As bandas de cor branca, feitas de estuque ou gesso, são aplicadas em superposição; ao número de seis em toda a sua fachada, as quais serão designadas por nós com o termo "lintel" para as poder descrever. $\mathrm{O}$ primeiro lintel encontra-se localizado a cerca de $0,50 \mathrm{~m}$ da base da parede (da torre) que assenta sobre a plataforma irregular de génese romana; o segundo lintel foi traçado aproximadamente $1,60 \mathrm{~m}$ do solo e seguem-se outros três lintéis, possuindo entre si aproximadamente $0,80 \mathrm{~m}$. O revestimento do quinto lintel desapareceu quase por completo. É provável que existisse um sexto lintel até ao topo da torre, contudo são quase nulos os seus vestígios.

A inscrição oficial nivelada que acabámos de referir, encontra-se no quarto lintel a $4.50 \mathrm{~m}$ do solo. Os outros grafitos encontram-se localizados num espaço da fachada com inicio no terceiro lintel até á base da torre, perfazendo aproximadamente $1,90 \mathrm{~m}$ acima do solo, prefigurando um espaço acessível a um indivíduo.

A localização dos grafitos e seu significado são cruciais para analisar o contexto almóada de Alcácer. Na verdade, eles estão na fachada norte da torre, enfrente ao espaço rural que confina com o território cristão, permitindo deste modo "ler" os grafitos num contexto da ğihād / guerra santa, contudo encontram-se do lado oposto ao rio e da actividade piscatória, comercial e de construção Naval. Eles dão a impressão de uma espécie de apresentação das actividades deste sítio , como se fossem a página introdutória de um livro, mesmo que alguns deles tenham sido executados de uma forma desajeitada. Este suposição é reforçada pelo fato de que os grafitos apresentam dois conjuntos: primeiro um registo oficial gravado na mais suave do quarto lintel, enquanto os restantes

37 Marquez Bueno, S. et Gurrarián Daza, P., Cáceres: una punta de lanza almohade frente a los reinos cristianos, Cáceres, 2005; Azuar Ruiz R., «Aspectos simbolicos de la arquitectura militar almohade» in Los Almohades: problemas y perspectivas, 2 vols., Madrid, 2005, pp. 123-147.

Conimbriga, 49 (2010) 183-224 
foram espalhados ao longo da fachada da torre, procurando deste modo amplificar e ilustrar aspectos do quotidiano, no âmbito do religioso e do económico. Eles aparecem como uma espécie de comentário que poderia dar suporte ao registo.

Os traços dos grafitos permitem observar que estes foram executados com um pico, nos dois tipos de suporte que descrevemos, a argamassa "militar" e o estuque usado nos lintéis. No caso do grande barco, verificamos que as linhas têm um carácter geométrico, o mesmo acontecendo noutras composições e em algumas letras árabes; no caso do peixe/cachalote, também em taipa militar, é patente as formas arredondadas do animal, assim como nas contas de âmbar que escapar da sua boca. É óbvio que mãos diferentes estiveram envolvidas na elaboração destes grafitos. É possível comparar alguns destes com os descritos por Carmen Torres Barceló no seu artigo Los escritos árabes de la Rabita de Guardamar. ${ }^{38}$

Tendo em conta o conjunto numeroso de grafitos identificados e não sendo possível analisá-los na totalidade neste trabalho, achamos adequado por agora mostrar aqueles que nos parecem mais relevantes, caso do barco sobre um conjunto de ondas, alguns barcos de pesca, um símbolo berbere, um peixe grande que aparenta ser um cachalote, assim como duas palavras em árabe sendo uma delas Deus/Allāh.

\section{O grande barco [Fig. 6 e 7 ]}

Corresponde a um grafito que foi gravado sobre a parede, pouco acima da plataforma de génese romana. As primeiras linhas; a linha de base e o início da quilha no fundo das ondas, foram descobertos em 2003, mas os elementos obtidos na altura não permitiram efectuar nenhuma leitura coerente do que seria. Em 2009, podemos identificar mais elementos, permitindo desta vez reconhecer o conjunto como representando a estrutura de um barco, donde se realçava os elementos mais importantes. Admitimos a existência de mais elementos, contudo o elevado grau de deterioração da parede não permitiu de momento a

38 Barceló Torres, C. "Los escritos árabes de de la Rábita de Guardamar", in El-ribāt califal, Excavaciones e investigaciones (1984-1992), Collection de la Casa de Velazquez, vol. n85, Madrid, 2004, pp. 131-145, foto 80 p. 136.

Conimbriga, 49 (2010) 183-224 
identificação de mais elementos. ${ }^{39}$ A zona de contacto do barco com as ondas permitiu identificar um peixe. No lintel inferior pode-se ler a palavra árabe $b a h r^{40}$ Este termo significa tanto "mar" ou "rio" quando este se trata de um rio grande. De facto a documentação medieval cristã de Alcácer refere-se bastantes vezes o rio Sado como o mar - outro exemplo clássico é o Tejo - . Estamos perante a confirmação de que para o poder islâmico, o Sado seria um rio do Sul de Portugal. Face ao exposto, a representação deste barco tanto significa que este esteja a navegar no Sado como no Atlântico [Fig. 8].

Com um comprimento de $90 \mathrm{~cm}$ e uma altura no ponto mais alto de $50 \mathrm{~cm}$, o navio repousa sobre um conjunto de ondas altamente estilizados que vão até aos $30 \mathrm{~cm}$. Alguns elementos são legíveis ao nível das ondas; alguns têm a forma de letras em árabe «२» (ḥầ) 《د» (dâl), no início, meio e fim da palavra. Será que querem representar peixes, golfinhos por exemplo (!), dada a sua abundância na região? O Estuário do Sado é actualmente famoso pela população de golfinhos. ${ }^{41}$ Logo acima destes motivos, duas linhas estilizam um barco aparentemente agarrado ao casco do navio. A pilha de sal ocupa uma plataforma razoavelmente grande com um peixe perfeitamente desenhado para a base. As linhas, feitas com um ponto, são bastante profundas, de dois a três milímetros. As incisões são livres; apesar de sedimentos recentes cobrirem algumas partes, atestamos que o estilo geométrico é marcante.

Sobre o grande tamanho deste grafito, deve notar-se que no artigo de Andre Bazzana, Les graffitis de bateaux dans al-Andalus et au Maghreb al-Aqsâ, ${ }^{42}$ a maioria dos documentos esgrafitados, estudados, são pequenos ou de dimensão média, como a do barco recentemente descoberto pelos membros do Campo Arqueológico de Mértola ${ }^{43}$, cujo tamanho é inferior a dez centímetros.

As fontes árabes medievais fornecem-nos informações importantes no que concerne à descrição dos navios, incluindo as embarcações

39 Bazzana, A., loc. cit.

40 Dunlop, D.M. «Bahr», Encyclopédie de l'Islam 2, vol. I, Leyde.

41 A população mais idosa de Alcácer, ainda se lembra da existência de golfinhos que subiam o rio até Vale de Guizo

42 Bazzana, A. loc. cit.; Bazzana, A., Lamblin, M.P., «Los graffiti médiévales des Castell de Dénia» in Catálogo, Dénia (Publicaciónes des Museo Arqueológico), 1984. de Mértola.

43 Em curso de estudo por Susana Gomez e Virgílio Lopes, Campo Arqueológico Conimbriga, 49 (2010) 183-224 
utilizadas pelos Almóada na conquista de Maiorca em 1203, que seriam à volta de trezentos e provavelmente contemporâneos dos que foram esgrafitados em Alcácer. Guilhermo Roselló Bordoy ${ }^{44}$ e Jorge Lirola Delgado ${ }^{45}$ descrevem nos seus respectivos trabalhos estes tipos de barcos, apresentando um léxico árabe rico e variado no que diz respeito às funções ligadas à navegação. Christophe Picard ${ }^{46}$ também nos informa sobre outros modelos de barcos, incluindo um deles, que poderia coincidir com o barco grande do nosso grafito, al-markaba al-hammala, que pode ter servido para o transporte de carga ou de tropas, conforme as situações a que estava sujeito. Num período anterior ao que concerne ao contexto histórico dos grafitos de Alcácer, no final da segunda metade do século XI, Ibn Ḥayyān ${ }^{47}$ sugere a existência de um modelo de navio, o marākib ġarbiyya, semelhantes aos já mencionados aqui e apropriado para a navegação no Ocidente muçulmano.

\section{Os navios secundários e o símbolo do tridente berbere [Fig. 9 e 10]}

Outros traços menos elaborados de barcos existem no segundo lintel. Eles representam uma espécie de friso contínuo, composto por simples barcos que se parecem com as fotos acima; o seu tamanho situa-se entre 15 e $20 \mathrm{~cm}$. O seu traço é profundo e espesso, este é certamente devido à natureza do suporte, mais suave do que a taipa militar e dá a impressão de um desenho feito sobre o gesso. O ducto árabe, da direita para a esquerda, transparece na leitura destes grafitos, dando a impressão particular de fazer sair o motivo da parede e de materializar o movimento deste sobre a água. Estes barcos representam o qārib descrito por Christophe Picard, "qui navigue aussi bien sur les rivières comme

44 Rosselló Bordoy, G., L'Islam a les Illes balears, Palma de Majorque, 1968; idem, Terminología naval según las fuentes históricas y lexicográficas Naves Andalusíes en Cerámicas Mallorquinas, Palma de Majorque, 1993, pp. 29-67.

45 Lirola Delgado, J., El Poder Naval de al-Andalus en la época del Califado Omeya, Madrid 1993; idem, «Tráfico marítimo de pasajeros y de mercancías» in Arqueologia Medieval 9, Mértola- Porto 2005, pp. 99-104.

46 Picard, Ch., L'océan Atlantique musulman: de la conquête arabe à l'époque almohade, Paris, 1997, pp. 302-305.

47 Ibn Ḥayyān, Kitāa al-muqtabis fì ta'rīh riğāl al-andalus, muqtabis $V$, éd. A. Hağğ̄̄i, Beyrouth, 1967, trad. E. Garcia Gomez, Madrid, 1965.

Conimbriga, 49 (2010) 183-224 
en mer"48; um modelo que é particularmente interessante no contexto geográfico de Alcácer, pois podem ser usados pelos marinheiros que operam tanto no Sado como no Oceano Atlântico.

\section{O barco com tridente(s) [Fig. 11]}

Um outro grafito, localizado na argamassa entre o segundo e o terceiro lintel, a uma altura de $1,80 \mathrm{~m}$ e com um comprimento de $65 \mathrm{~cm}$, representa um tipo de barco bastante particular, porque é atravessado por um símbolo, um tridente no centro e termina aparentemente por um segundo tridente. A leitura do traço sugere que se trata do desenho de um leme [Fig. 12]. O tridente central possui um traçado geométrico ao contrário do traço correspondente a traço que o atravessa e que sugerimos corresponder a uma embarcação muito estilizada. O tridente representa um símbolo berbere certificado. ${ }^{49} \mathrm{~A}$ interpretação deste grafito sugere, que ao contrário dos barcos que estão logo abaixo, estaremos aqui na presença de um conjunto mágico associado ao barco, neste caso, uma embarcação que contem, um sinal benéfico e de conquista.

\section{O tridente "aurelado" [Fig. 13]}

Um outro tridente é representado abaixo do grande barco, para a esquerda da palavra baḥr/mar ou rio. Ele encontra-se "aureolado" com várias linhas verticais desenhado num arco de círculo. Ele complementa outros elementos simbólicos da fachada. O traço é muito espesso, com mais ou menos $5 \mathrm{~mm}$ de largura; um depósito de sedimentos parece ter reforçado o seu traçado.

\section{O cachalote [Fig. 14 e 15]}

A 1,70 m acima do solo, acima e ligeiramente à direita em relação ao barco, no canto direito da parede, notamos um grupo de círculos de 3-4 centímetros de diâmetro, bem visíveis, marcados na argamassa.

48 Picard, Ch., loc. cit. p. 303.

49 Belfiore, J. Cl., Dictionnaire des croyances et symboles de l'Antiquité, Paris, 2010; Menning, M., Dictionnaire des symboles, Paris, 2005; Morel, C., Dictionnaire des symboles, mythes et croyances, Paris, 2004; Chebel, M., Dictionnaire des symboles musulmans: rites, mystique et civilisation, Paris, 2000.

Conimbriga, 49 (2010) 183-224 
Estes círculos não podem ter surgido como acidente. Ao olhar mais de perto, é possível identificar cerca de três deles, junto a uma parcela do corpo de um peixe, com listras na sua parte superior. O peixe tem a boca aberta e os círculos continuam a surgir a partir desta lacuna num espaço ao longo de $60 \mathrm{~cm}$. A lonjura do desenho da boca e de uma parte do corpo têm um máximo de $12 \mathrm{~cm}$ sobre uma altura de $15 \mathrm{~cm}$. A linha, com uma profundidade média de dois milímetros, foi também desenhada por uma ponta [Fig. 16].

Um pouco mais abaixo, à esquerda, descobrimos uma letra em árabe, um pouco deformada pelo sedimento, mas legível; trata-se da palavra 'anbar, âmbar, com um comprimento de linha de $5 \mathrm{~cm}$, com um traço mais profundo do que o utilizado no peixe [Fig. 17]. É provável que tenha sido efectuado com outro tipo de ferramenta, com uma ponta mais fina. A descoberta desta inscrição veio reforçar a ideia de que o peixe representado é, de facto, um cachalote. Como mencionado anteriormente, as fontes árabes que descrevem Alcácer estipulam que esta se localiza na Costa do Âmbar, ${ }^{50}$ al-Ğūn al-'anbarī. O âmbar que vem das concreções intestino dos cachalotes, era comum na costa sul de Lisboa. As fontes também mencionam que os presentes, incluindo o âmbar, foram oferecidos em numerosas ocasiões. A representação deste peixe contendo âmbar nas suas entranhas e a cuspir, é um testemunho que melhor ilustra esta informação [Fig. 18].

\section{Algumas inscrições}

A nossa curiosidade e a nossa atenção concentrou-se inicialmente no estudo de dois grafites que nós consideramos de monumental, "o grande barco "e" cachalote". Posteriormente detectamos algumas inscrições em árabe. Ao contrário dos grafitos referentes ao barco e ao cachalote, localizada no lado direito da fachada da torre e a sucessão de barcos no segundo lintel também nesse lado, ao prosseguimos em direcção ao

50 Yāqūt al-Hamawī, Mu'ğam al-buldān, 7 vols, 2e éd., Beyrouth, 1995. Abū 1-Fidā', Taqwīm albuldān. Géographie d'Aboulféda, éd. M. Reinaud et M.G. de Slane, Paris, 1840; trad. M. Reinaud, St. Guyard, Paris, 1848; Ruska, J. (Plessner, M.), «'Anbar», Encyclopédie de l'Islam 2, t I, pp. 498-9; Picard, Ch., loc. cit. p. 363, p. 468; Lewicki, T., «Les sources arabes concernant l'ambre jaune de la Baltique», in Archaeologia Polonia XXIII, Wroclaw, 1984, pp. 121-142.

Conimbriga, 49 (2010) 183-224 
centro da fachada, encontramos varias inscrições isoladas, inclusive o nome de Allāh / Deus e o nome Ḥasan que foram gravadas no centro da fachada da torre, ligeiramente para a esquerda.

O nome de Deus / Allāh [Fig. 19 e 20]

A inscrição Allāh foi gravada sobre um comprimento de $30 \mathrm{~cm}$ e entre 10 e $20 \mathrm{~cm}$ altura. A inscrição encontra-se isolada, a $2 \mathrm{~m}$ acima do solo, bem no centro da fachada Torre 13. Há uma dúvida no significado desta palavra porque o "alif" está ausente no princípio. Ele poderia envolver assim a contração da expressão "b-ismi-llāh".

\section{O nome Ḥasan [Fig. 21]}

A inscrição Ḩasan encontra-se gravada a 1,50 m acima do solo, em pleno centro da fachada da Torre 13; o comprimento é de $40 \mathrm{~cm}$ desenvolvendo-se em altura entre 5 a $10 \mathrm{~cm}$. $\mathrm{O}$ traço destes dois grafitos é bom possuindo $2 \mathrm{~mm}$ de profundidade, excepto a última letra do Hasan, com mais espessura.

Em conclusão, este grupo de grafitos apresentam um carácter excepcional por várias razões. Este é o primeiro conjunto desta envergadura, de época medieval muçulmana descoberta até agora em Portugal, Ġarb al-Andalus. De fato, se tais testemunhas são numerosos e visíveis em Espanha, no resto do al-Andalus, tal não era o caso de Portugal, apesar da presença de espaços ou fortificado, famosas ou conhecidas como Silves, Mértola, Palmela, Aljezur, assim como de outros. Este conjunto de inscrições materializam as informações já conhecidas e relatadas nas fontes históricas medievais, árabes e cristãs, referentes à presença muçulmana nesta região.

Os grafitos, pela sua localização e pelo seu significado, são as testemunhas essenciais que documentam o desenvolvimento da ğihăd /guerra santa em Alcácer, e da sua resistência em face da reconquista pelos exércitos cristãos. Eles também ilustram a acção que jogaram as actividade económica e social nesta região até à primeira metade do século XIII. Nomeadamente, a actividade económica relacionada com a construção naval, comércio do sal, salga de peixe e âmbar, mostrando a 
persistência desde os tempos romanos e certamente aproveitando algumas infra-estrutura pré-existentes. Esta documentação confirma a importância da localização geográfica e estratégica do sitio, tanto como porta aberta para o Atlântico, como de acesso às terras do interior; trata-se de uma posição essencial no século XII e início de século XIII, tendo em conta as relações com os outros portos muçulmanos do Mediterrâneo.

Mas estes testemunhos também colocam vários tipos de perguntas. Qual é o verdadeiro destino do "grande barco"? É apenas um navio de comércio ou uma embarcação mista que pode ser usada na ğihād, a guerra santa, tal como a conhecemos poder existir neste contexto? Os desenhos da pilha de sal e o peixe que figuram sobre o barco, poderá fazer pensar que estamos perante comércio de peixe salgado, mas o que dizer da madeira, numa região povoada de florestas e realçada nas crónicas, assim como de outros produtos agrícolas? Quanto às inscrições de nomes próprios, são eles apenas o traço deixado por indivíduos anónimos ou estaremos na presença de funcionários titulares ou dignitários?

Como observamos anteriormente, estamos perante um ano de trabalho de levantamento e análise destes grafitos. Muita investigação continua por fazer na identificação e leitura, admitindo que outros grafitos poderão ter escapado à nossa atenção, mas continuamos a examinar cuidadosamente a fachada da torre 13 do espaço fortificado de Alcácer do Sal, em busca de informações complementares, tanto para tentar responder a essas perguntas, como para desenvolver os campos de investigação já referidos.

\section{Uma parte do mapa do al-Andalus segundo Ibn Ḥawqal, ms. 3346, Istambul [Fig. 22]}

O mapa apresentado provem do manuscrito árabe $\mathrm{n}^{\circ} 3346$ do antigo fundo Seray de Istambul. Esta cópia, datada 479/1086, serviu de suporte principal à edição do texto de Ibn Hawqal feita por de Goeje, Leiden, 1873, e da qual foi efectuada uma segunda edição por Johannes Hendrik Kramers, Leiden 1938. Estas edições foram combinados e traduzidos do árabe na publicação posterior de Johannes Hendrik Kramers, redigida com Gaston Wiet, em dois volumes, Paris-Beirute 1964 e intitulado Configuration de la terre (Kitāb șūrat al-arḍ). A última edição de 2001 repete nesta edição, juntando-se um prefácio de André Miquel. Em ambas as edições, todos os mapas que aparecem no texto 
de Ibn Hawqal foram reproduzidos em duplo exemplar comportando uma numeração dos sítios que permite melhor localizar na tradução do texto, os topónimos conhecidos em caracteres latinos.

É interessante notar que na edição do texto em árabe de 1938, Johannes Hendrik Kramers dá como leitura Qașr Banī Wardāsan para Alcácer do Sal, página 115, com uma nota de referência a Wardāsan-Ibn Waddāsan enquanto que na tradução de 1964, indica na nota da página 45, "Qașr Banī Wardāsan fait songer à Qașr Abī Dānis (Alcácer do Sal)."

No mapa do Al-Andalus estabelecido por Ibn Ḥawqal (século X) no Kitāb şūrat al-arḍ que foi reproduzido por Johannes Hendrik Kramers, Alcácer do Sal aparece com o topónimo de Qaşr Banī Warrās ou Qaşr Banī Waddās. (ver a figura 23). De acordo com a cópia do manuscrito apresentado, é difícil fazer a diferença entre as letras árabes "j" (rā) e “د" (dā), onde é possível fazer as duas leituras do topónimo [Fig. 23].

O aumento do mapa mostra também que se pode fazer outra confusão de leitura, desta vez referente á letra final da última palavra, um "ن" (nūn) ao invés de "w" (sīn), especialmente uma vez que não existem pontos diacríticos sobre a palavra, que não é o caso de dois termos, disposto em forma de cruz e que aparecem logo acima.

A questão colocada pelo uso do nome do lugar e a localização do facto sobre um mapa, são particularmente importantes para a análise de contexto histórico de Alcácer nos séculos IX e X. Foi nesse 875-876 que os Banū Dānis, expulsos de Coimbra, se instam no local, reforçando o ribāt aí existente. A cidade que se desenvolve em seu redor irá receber o seu nome (ver o enquadramento histórico de Alcácer). No seu texto, Ibn Hawqal, conhecido pelo testemunho directo que tinha dos lugares que descrevia, qualifica bem a cidade de "fortificado", madīna hașina, mas não usa o termo Qașr Abī Dānis, para a citar, usando apenas Qașr Banī Warrās ou Qașr Banī Waddās, topónimo que aparece no seu mapa mas que coloca um problema de leitura. Deve também especificar que o Kitāb șürat al-arḍ (século X) é a única fonte árabe onde Alcácer figura com este topónimo. O sitio de Alcácer perde assim o seu nome Qașr Abī Dānis no século X, embora alguns fontes árabes posteriores, recuperem esse nome, como são os casos de Ibn Hayyān (século XI), Ibn al-Abbār (século XIII), Abū-1 Fidā ‘ (século XIII-XIV) e al-Hịyarī (século XIV).

A referencia que faz Johannes Hendrik Kramers na sua edição do texto árabe (1938) com Banī Wardāsan Ibn Waddāsan não está incluída na tradução que ele publicou em 1964, e nem na edição com prefácio 
de André Miquel em 2001. Seria útil para esclarecer e responder a esta questão sensível de toponímia, consultar as outras três cópias do manuscrito que Johannes Hendrik Kramers utilizou em complemento do manuscrito fonte Istambul e sobre o qual ele estabeleceu o seu texto, a saber os exemplares das Bibliotecas de Bodlein, Leiden e Paris.

Sistema de transliteração do árabe adoptada: transliteração Arabica

\section{Bibliografia}

Fontes arabes (por ordem cronológica)

Ibn ḤAWQAL (Xe siècle), Kitāb șurat al- 'arḍ. Configuration de la Terre. Introduction et traduction avec index par J.H. Kramers, G.Wiet (2vol), Paris, 1964; Kramers, G.Wiet et A. Miquel, Paris 2001; Encyclopédie de l'Islam 2, t III, pp. 810-811. Ibn HAZM (XIe siècle), Ğamharat ansab al-arab, éd. Lévi-Provençal, Le Caire, 1948. Ibn ḤAYYĀN (XIe siècle), Kitāb al-muqtabis fì ta'rīh riğāl al-andalus, éd. Ḥağğ̄î, A., Beyrouth, 1965; trad. Garcia Gomez, E., Madrid, 1967; Muqtabis V, éd. Chalmeta, Corriente et Subh, Madrid, 1979.

al-IDRĪSĪ (XIIe siècle), Kitāb nuzhat al-muštāa $q$ fi-htirāk al-afāq, éd. Instituto Universitario Orientale di Napoli e Instituto per il Medio e Estremo Oriente, al-Idrīsī, opus geographicum, Napoles-Roma, 1975; trad. R. Dozy et M. De Goeje, Description de L'Afrique et de L'Espagne, nouvelle édition, Leyde, 1968, p. 544, trad. p. 219; trad. relative à l'Occident, H. Bresc, A. Nef, Idrīsī. La première géographie de l'Occident, Paris, 1999; (Muhāj) Uns al-muhāj wa rawḍ al-furāh, éd. et trad. de M. J. Mizal, Los Caminos de al-Andalus en el Siglo XII, Madrid, 1989, p. 49, trad. p. 82; G. Oman, «al-Idrīsi», Encyclopédie de l'Islam 2, t III, pp. 1058-1061.

IBN al-ABBĀR (XIIIe siècle), Kitāb at-takmila li-kitāb aș-șila, (2 vol), éd. F. Codera, Madrid 1888-1889, éd. 'I. 'A. al-Husayn̄̄, Le Caire-Bagdad, 1956; M. Ben Cheneb-(Ch. Pellat), «Ibn al-Abbār», Encyclopédie de l'Islam 2, t III, pp. 694-695.

YĀQŪT al-HAMAWĪ (XIIe-XIIIe siècle), Mu '̆gam al-buldān, 2e éd., 7 vols, Beyrouth, 1995; trad. partielle de Gamal Abd al-Karim, «La España musulmana en la obra de Yāqūt (S. XII-XIII)» in Cuadernos de Historia del Islam, 6, Granada,1974; Cl. Gilliot, «Yāḳūt al-Rūmī», Encyclopédie de l'Islam 2, t XI, éd. anglaise, pp. 264-266.

IBN ABĪ ZAR' (XIIIe-XIVe siècle), Kitāb al-'anīs al-mutrib bi-rawḍ al-qirțâs, éd. Rabat 1973; trad. Huici Miranda, Textos Medievales, 2e éd., Valence, 1964; H.R. Idris, «Ibn Abī Zar'», Encyclopédie de l'Islam 2, t III, p 717.

ABŪ l-FIDĀ' (XIIIe-XIVe siècle), Taqwīm al-buldān. Géographie d'Aboulféda, éd. M. Reinaud et M.G. de Slane, Paris, 1840; trad. M. Reinaud, St. Guyard, Paris, 1848; H.A.R. Gibb, «Abū 1-Fidā», Encyclopédie de l'Islam 2, t I, p 118.

Conimbriga, 49 (2010) 183-224 
IBN 'IDARĪ (XIIIe-XIVe siècle), al-Bayān al-mugrib fì ahbār mulūk al-Andalus, éd. Dozy, R., Leyde 1948-1951.

al-ḤIMYARI (XIVe siècle), La Péninsule ibérique au Moyen Âge d'après le Kitāb al-rawd al-mi 'țâr. Texte arabe des notices relatives à l'Espagne, au Portugal et au Sud-Ouest de la France, trad. de E. Lévi-Provençal, Leyde, 1938; éd. Abbas, I., Beyrouth, 1975; trad. partielle de Maestro Gonzalez Valencia, 1963, pp. 161-162, trad. p. 194. T. Lewicki, «Ibn 'Abd al-Mun'im al-Ḥimyārī», Encyclopédie de l'Islam 2, t III, pp. 697-698.

\section{Obras e artigos de referencia}

ACIEN ALMANSA et CRESSIER, P., «Las inscripciones arabes de Senes (Almeria)», in Homenaje a Manuel Ocaña Jimenez, Cordoue, 1990, pp. 22-31.

AOUNI, L.M., "L'épigraphie et la ville, le cas de Fés à l'époque Mérinide», in $I I$ Congreso internacional, La cuidad en al-Andalus y el-Magreb (Algeciras), El Legado Andalusi, 2002, pp. 75-97.

ARCAS CAMPOY, M., Teoria juridica de la guerra santa del granadino Ibn Abi Zamanim, C.E.M.A., 2004. http://alyamiah.com/cema/modules.php?name=Ne ws\&file $=$ article $\&$ sid $=256$

AGUILAR, V., «Instituciones Militares: El Ejército» in Viguera $\mathrm{M}^{\mathrm{a}} \mathrm{J}$. (coord), El retroceso territorial de al-Andalus. Almorávide y Almohades. Siglos XI al XIII. Vol. VIII/** de Historia de España dir. Ramón Menéndez Pidal, Madrid, 1997, pp. $189-208$.

ALARCÃO, A. et MAYET, Fr., Les amphores lusitaniennes, Typologie, Production, Commerce, Paris, 1990.

AZUAR RUIZ, R. et alii., El-ribāt califal, Excavaciones e investigaciones (1984-1992), Collection de la Casa de Velazquez, vol. n85, Madrid, 2004; idem, «Aspectos simbolicos de la arquitectura militar almohade» in P. Cressier, M. Fierro y L. Molina, Los Almohades: Problemas y Perspectivas, 2 vols., Madrid, 2005, pp. 123-147.

BARCELÓ TORRES, C. et LABARTA, A., «Dos inscriptiones arabes halladas en Alcácer do Sal» in Setúbal Arqueologica 8, Setubal, 1987, pp. 265-70; idem, «Inscripciones arabes portuguesas: situacion actual», in Al-Qanțara, VIII, Madrid1987, pp. 395-420; idem, «Los escritos árabes de la Rábita de Guardamar» in El-ribāt califal, Excavaciones e investigaciones (1984-1992), Collection de la Casa de Velazquez, vol. n85, Madrid, 2004, pp. 131-145.

BARRERA MATURANA, J.I., «Iconografia marginal: graffitos historicos en la casa nazari de calle Buenaventura, 2 (Granada)», in De Arte, 7, Grenade, 2008, pp. 153-166.

BASSET, R., Mélanges, Etudes Nord Africaines et Orientales publiées par l'Institut des Hautes Etudes Marocaines, Paris, 1925.

Conimbriga, 49 (2010) 183-224 
BAZZANA, A., «Les graffiti de bateaux dans al-Andalus et au Maghreb al-Aqsâ», in Les Cahiers de l'Urbanisme, Mélanges d'archéologie médiévale, Liber amicorum en hommage à André Matthys, Bruxelles, 2006,pp.16-34; idem, «Signale et signum..., l'objet porteur d'indices et d'informations. Quelques exemples dans l'Occident musulman médiéval» in L'objet de main en main, Mélanges de la Casa Velazquez n ${ }^{\circ} 45$, Madrid, 2010, pp. 33-45.

BAZZANA, A., LAMBLIN, M.P., Los graffiti médiévales des Castell de Dénia, Catálogo, Publicaciónes Museo Arqueológico, Dénia 1984.

BERTI, G.,, «Consideraciones sobre los "Bacini” utilizados en la decoración de las iglesias Pisianas de los siglos XI y XII» in Naves Andalusies en Cerâmicas Mallorquinas, Palma de Majorque, 1993, pp. 11-19.

BERTI, B.et RIZZO, C., «I Porti della Toscana ed il Loro ruolo negli scambi commerciali del Mediterraneo tra X e XIII secolo» in Arqueologia Medieval 9, Mértola-Porto, 2005, pp. 161-179.

BLOT, M. L., «Problemáticas da Arqueologia Nautica e Portuária no quadro do estudo de portos antigos e medievais em Portugal» in Arqueologia Medieval 9, Mértola-Porto, 2005, pp. 207-220.

BOISSELLIER, S., «Réflexions sur l'idéologie portugaise de la reconquête. XIIe-XIVe siècles», in Mélanges de la Casa Velazquez, Tome XXX-1, Madrid, 1994, pp. 139-165.

BOUTCHICH, B., «Les Ports Méditerranéens en Occident Musulman à travers la litetérature Géographique arabe du Moyen Âge» in Arqueologia Medieval 9, Mértola-Porto, 2005, pp. 41-46.

BRAGA, I., Entre a Cristandade e o Islão (séculos XV-XVII): cativos e renegados nas franjas de duas sociedades em confronto, Ceuta, 1998.

CAHEN, Cl., L'Islam des origines au début de l'empire ottoman, (1ère éd., Paris, 1970), Paris, 1995.

CARMONA GONZÁLEZ, A., «LA FRONTERA: Doctrina Islâmica e Instituciones Nazaríes» in Actas del Congreso-La Frontera Oriental Nazari como Sujeto Histórico (S. XIII-XIV) Lorca-Vera, 22 a 24 de noviembre 1994, Lorca, 1997, pp. 47-57.

CARVAlHO, A. R. «Alcácer do Sal entre 1191 E 1217 (I Parte)» in Neptuno 3, ADPA2005; idem, «Alcácer do Sal entre 1191 e 1217: Os dias em que Qasr al-Fath foi sede do Império Almóada», in Neptuno 6, ADPA, 2005, pp. 12-13; idem, «O Santuário do Senhor dos Mártires em contexto Islâmico: Alguns elementos para o seu estudo» in Neptuno 7, 2006, pp. 4-6 ADPA; idem, «A Representação Iconográfica do Senhor dos Mártires e Alcácer do Sal no Século XIII» in Neptuno 8, 2006, pp. 6-9 ADPA; idem, «A Torre Medieval de Santa Catarina de Sitimos: Elementos para o Estudo do Sistema Defensivo de Alcácer do Sal em Contexto Almóada», ADENDA on-line Al Madan 15, 2007, http://www.almadan.publ.pt/ AdendaElectronica\%20(geral).htm; idem, «Al-Qasr: A Alcácer do Sal Islâmica», Roteiro - Cripta Arqueológica do Castelo de Alcácer do Sal, Lisbonne, 2007, pp. 43-56; idem, «Alcácer: Alcácer do Sal Medieval e Cristã», Roteiro - Cripta Arqueológica do Castelo de Alcácer do Sal, Lisbonne, 2007, pp. 57-68; idem, 
«Alcácer do Sal no Final do Período Islâmico (Séculos XII-XIII): Novos Elementos sobre a $1^{\text {a }}$ Conquista Portuguesa», Colecção Digital - Elementos para a História do Município de Alcácer do Sal, $n^{\circ}$ 1, 2008, http://www.cmalcacerdosal.pt/PT/ Actualidade/Publicacoes/Paginas/EstudosdoGabinetedeArqueologia.aspx; idem, «A Antiguidade Tardia e a Islamização na Costa Sesimbrense. O Tempo do Risco» in Carte archéologique de Sesimbra, coord. M. Calado e L. J. Gonçalves, Sesimbra, 2009, pp. 172-191; idem, «O Final da Presença Islâmica na Região de Ourique (1160-1250): Introdução a uma questão em aberto», Cadernos Culturais d'Ourique, Orik Ano IV, 2009, p. 11-18.

CARVALHO, A.R., FARIA, J.C. et FERREIRA, M. AIRES, (Al-QAȘR) Alcácer do Sal Islâmica: Arqueologia e História de uma Medina do Garb al-Andalus (séculos VIII-XIII), Alcácer do Sal, 2008.

CASTRILlO MÁRQUEZ, R., «Instituciones Politicas» in $\mathrm{M}^{\mathrm{a}} \mathrm{J}$. Viguera, coord., El retroceso territorial de al-Andalus. Almorávides y Almohades. Siglos XI al XIII. Vol. VIII/** de Historia de España, dir. Ramón Menéndez Pidal, Madrid, 1997, pp. 129-145.

CORNU, G., Atlas du Monde Arabo-Islamique à l'Epoque Classique (IXe-Xe siècles), Leyde, 1985.

COTTART, N.D., «Un manuscrit biographique conservé à Meshed» in Cahiers d'Onomastique arabe 1981, Paris, 1982, pp 115-118; idem,édit. de Georges Vajda, La transmission du savoir en Islam, VIIe-XVIIIe s., Londres, 1983; idem, Mise à jour du traitement informatique des données biographiques de l'Onomasticon Arabicum, CNRS/IRHT, Paris, 1986; idem, «Mālikiyya», Encyclopédie de l'Islam 2, pp. 263-268; idem «Le livre de Kalila et Dimna» in Le livre au Moyen-Âge, sous la direction de Jean Glénisson, pp. 144-145, Paris, 1988; idem, participation à la base de données de l'IRHT-CNRS Onomasticon Arabicum-prosopographie de l'Islam médiéval, Paris, 2009 avec la mise en ordinateur des données biographiques du Šadarât al-ḍhab d'Ibn al-'Imād, du Šadarāt an-nūr az-zakiyya de Muhammad Mah̆lūf et d'Al-Muqtadab min kitāb tuḥfat al-qādim li-ibn al-Abbār de Balfiq̄ī, (éd. Al-Abyārī /Le Caire, 1957), (voir le site Aedilis de l'IRHT), mise à jour 2010; idem, «Narbonne dans les sources arabes» in Dynamique lagunaire en Narbonnaise/ANR Dylan, (sous presse).

CRESSIER, P., «De un Ribat a otro: Una hipótesis sobre los Ribāt-s del Magrib al-Aqșà (siglo IX-inicios del siglo XI)» in El Ribāt Califal: Excavaciones e investigaciones (1984-1992), Casa de Velázquez, 2004, pp. 203-221.

CRESSIER P., FIERO M. et MOLINA L., Los Almohades: Problemas y Perspectivas, 2 vols., Madrid, 2005.

DEVERDUN, G., «Kașaba», encyclopédie de l'Islam 2, Vol. IV, pp. 684-686.

ETIENNE, R., MAKAROUN, Y. et MAYET, Fr., Un grand complexe industriel à Troia (Portugal), Paris, 1994.

ETIENNE, R. et MAYET, Fr., édit., Itinéraires lusitaniens, Trente années de collaboration archéologique luso-française, Paris; idem 2000, Le vin lusitanien, Paris, 1997; idem, Salaisons et sauces de poissons hispaniques, Paris, 2002; idem, L'huile hispanique, Paris, 2004.

Conimbriga, 49 (2010) 183-224 
FABIÃO, C., «Cetárias, Anforas e Sal: A Exploração de Recursos marinhos na Lusitania» in Estudos Arqueologicos de Oeiras, $n^{\circ}$ 17, Oeiras, 2009, pp. 555-594.

FERREIRO ALEMPARTE, J., "Arribadas de Normandos y Cruzados a las Costas de la Peninsula Iberica», Madrid, 1999.

FIERRO, M., «La Religion» in $\mathrm{M}^{\mathrm{a}} \mathrm{J}$. Viguera, coord., El retroceso territorial de al-Andalus. Almorávides y Almohades. Siglos XI al XIII. Vol. VIII/** de Historia de España, dir. Ramón Menéndez Pidal, Madrid, 1997, pp. 437-546.

FRANCO SÁNCHEZ, F., «La Frontera Alternativa: Vias y Enfrentamientos IslamoCristianos en la Mancha Oriental y en Múrcia», in Actas del Congreso-La Frontera Oriental Nazari como Sujeto Histórico (S. XIII-XIV), 1997, Lorca-Vera, 22 a 24 de noviembre 1994, Lorca, 1997, pp. 237-251.

FLÜGEL, G., Nuğūm al-furqān fì ațrāf al-qur'ān - Concordantiae corani arabicae: ad literarum ordinem et verborum radices, Leipzig, 1842.

GARCÍA FITZ, F., Las Navas de Tolosa, Barcelone, 2005.

GARCÍA SANJUAN, A., «La caracterizacion de Al-Andalus en los textos geograficos arabes orientales (siglos IX-XV)» in Norba, Revista de Historia, vol. 19, La Rioja, 2006, pp. 43-59.; idem, «La caracterizacion geografica del Garb al-Andalus en las fuentes arabes medievales», in Medievalista, $\mathrm{n}^{\circ} 6$, Lisbonne, 2009, pp. 2-11.

GONZALEZ GOZALO, E., «Tipos nauticos en los graffiti mallorquines (siglos XIVXIX)» in Actes du VIIle colloque international de glyptographie d'Hoepertingen Euregio (du 29 juin au 4 juillet 1992), Braine-Le-Château,1993.

GUTIÉRREZ LLORET, S., «El Ribat antes del Ribat: El contexto material y social del Ribāṭ Antiguo» in El Ribāt Califal: Excavaciones e investigaciones (1984-1992), Casa de Velázquez, Madrid, 2004, pp. 73-87.

HUICI MIRANDA, A., «Los Almohades en Portugal», in Anais da Academia Portuguesa de História, vol V, Lisbonne, 1945, pp. 11-74; idem, História Politica del Império Almohade (Primera Parte), Tetuan 1956; idem, História Politica del Império Almohade (Segunda Parte), Tetuan, 1957.

JUSTINIO MACIEL, M., Antiguidade Tardia e Paleocristianismo em Portugal, Lisbonne, 1996; idem, «Tráfico Marítimo de Pasajeros y de Mercancíase» in Arqueologia Medieval 9, Mértola-Porto, 2005, pp. 99-104.

KHAWLI, A., 2001, «Le Garb al-Andalus à l'Epoque des Secondes Taifas (539552/1144-1157)» in Actes du Colloque Lisboa - Encruzilhada de Cristãos, Judeus e Muçulmanos, Arqueologia Medieval 7, Mértola-Porto, 1997, pp. 23-35.

LAGARDÈRE, V., Les Almoravides: Le Djihad Andalou (1106-1143), Paris, 1989; idem, «L'or du Bilād al-Sūdān et le monnayage almoravide (1039-1143)»inLes routes d'Al-Andalus: patrimoine commun et identité plurielle, Paris, 2001, pp. 21-34.

LÉVI-PROVENCAL, E., Inscriptions árabes d'Espagne, Leyde,1931; idem, «Les 'Mémoires' de 'Abd Allāh, dernier roi ziride de Grenade», in Al-Andalus, vol. III, Madrid, 1935, pp. 233-344; idem, «Les 'Mémoires' de ‘Abd Allāh, dernier roi ziride de Grenade(conclusion)», in Al-Andalus, vol IV, Madrid, 1936-1939, pp. 29-145; idem, «Deux nouveaux fragments des 'Mémoires' du roi ziride 'Abd Allāh de Grenade», in Al-Andalus, vol VI, Madrid, 1941-1942, pp. 1-63; idem, Histoire de l'Espagne musulmane, 3e éd., Paris 1999.

Conimbriga, 49 (2010) 183-224 
LEWICKI T., «Les sources arabes concernât l'ambre jaune de la Baltique», in Archaeologia Polonia XXIII, Wroclaw, 1984, pp. 121-142.

LIROLA DELGADO, J., El Poder Naval de al-Andalus en la época del Califado Omeya, Madrid, 1993.

LOMBARD, M., Espaces et réseaux du haut moyen âge, Paris, 1972.

MARQUEZ BUENO, S. ET GURRARIÁN DAZA, P., Cáceres: una punta de lanza almohade frente a los reinos cristianos, Cáceres, 2006.

MAYET, Fr. et TAVARES da SILVA, C., L'atelier d'amphores de Pinheiro (Portugal), 2 vols, Paris, 1998.

MAYET, Fr. et TAVARES da SILVA, C., avec la collaboration de Makaroun, Y., Le site phénicien d'Abul (Portugal), Comptoir et sanctuaire, Paris, 2000; idem, L'atelier d'amphores d'Abul (Portugal), Paris, 2002.

MARÍN, M., «La práctica del ribat en al-Andalus (ss. III-V/IX-XI)» in El Ribāt Califal: Excavaciones e investigaciones (1984-1992,) Casa de Velázquez, Madrid, 2004, pp. 192-201.

MARTÍNEZ NUÑEZ, Ma. A., «Al-Andalus y la documentacion epigrafica», in Fontes da Historia de al-Andalus e do Gharb, édit. A. Sidarus, Lisboa, 2000, pp. 89-115.

MATTOSO, J., «1096-1325» in História de Portugal. dir. J. Mattoso, Lisbonne, 1992, pp. 9-309.

MEOUAK, M., Pouvoir souverain, administration centrale et élites politiques dans l'Espagne Umayyade (II-IV/VIII-X siècles), Helsinki, 1999.

MIQUEL, A., La géographie humaine du monde musulman jusqu'au 11e siècle. Les travaux et les jours, 4 vols, Paris, 1988; idem, Al-Muqadassī, Damas, 1963.

MURPHEY, R., «Milh», Encyclopédie de l'Islam 2, t VII, pp. 57-60.

PADILLA, L., «El Ribat: institución espiritual y militar» in Arqueología Medieval, com., 2006, http://www.arqueologiamedieval.com/articulos/articulos.asp?id=75

PAIXÃO CAVALEIRO, A., FARIA, J. C. et CARVALHO, A.R., «O Castelo de Alcácer do Sal: Um projecto de Arqueologia Urbana» in Actas do II Encontro de Arqueologia Urbana, Braga, 1994, pp. 215-264; idem, «Contributo para o estudo da ocupação muçulmana no castelo de Alcácer do Sal: O Convento de Aracoelli» in Actes du Colloque «Lisboa-Encruzilhada de Cristãos, Judeus e Muçulmanos, 1997», Arqueologia Medieval 7, Mértola-Porto, 2001, pp. 197-209; idem, «Aspectos da presença Almóada em Alcácer do Sal (Portugal). Mil Anos de Fortificações na Península Ibérica e no Magreb (500-1500)» in Actas do Simpósio Internacional sobre Castelos Lisboa/Palmela, Palmela, 2001, pp. 369-383.

PASTOR QUIJADA, J., «Observaciones sobre la arquitectura naval» in Naves Andalusies en Cerâmicas Mallorquinas, Palma de Mallorca, 1993, pp. 21-27.

PEREIRA LOPES,, M. T., «Memórias Cruzadisticas do Feito da tomada de Alcácer (1217) (com base no Carmen de Gosuíno)» in Actas do $2^{\circ}$ Congresso Histórico de Guimarães, Guimarães, 1996, pp. 319-358; idem, Alcácer do Sal na Idade Média, Alcácer do Sal, 2007.

PÉREZ ALVAREZ, M. Á., Fuentes Árabes de Extremadura, éd. Universidade de Extremadura, 1992.

Conimbriga, 49 (2010) 183-224 
PÉREZ HIGUERA, Mª «El Arte» in M $\mathrm{M}^{\mathrm{a}} \mathrm{J}$. Viguera, coord., El retroceso territorial de al-Andalus. Almorávides y Almohades. Siglos XI al XIII. Vol. VIII/** de Historia de España, dir. Ramón Menéndez Pidal, Madrid, 1997, pp. 637-699.

PICARD, Ch., L'océan Atlantique musulman: De la conquête arabe á l'époque almohade», Paris, 1997; idem, La mer et les musulmans d'occident au Moyen Age,VIIIe-XIIIe siècle», Paris, 1997; idem, Portugal musulman (VIII-XIII siècles): L'Occident d'al-Andalus sous domination islamique, Paris, 2000; idem, «La navigation médiévale des musulmans entre Méditerranée et oceán Atlantique (IXe-XIIe Siécles)» in Arqueologia Medieval 9, Mértola-Porto, 2005, pp. 13-20; idem «Kașr Abī Dānis», Encyclopédie de l'Islam 2, t XII suppl., pp. 513-514, éd. anglaise.

de PLANHOL, X., Les fondements géographiques de l'histoire de l'Islam, Paris, 1968; idem, L'Islam et la mer. La mosquée et le matelot, VIIe-XXe siècle, Paris, 2000.

REI, A., "O Gharb al-Andalus em dois geógrafos árabes do século VII/XIII: Yâqût al-Hamâwî e Ibn Sa 'îd al-Maghribî̀, Instituto de Estudos Medievais FCSH-UNL FCT, Medievalista on line, Ano 1, no 1, 2005, http://www2.fcsh.unl.pt/iem/ medievalista/MEDIEVALISTA1/medievalista-andalus.htm; idem, «Santarém e o vale do Tejo, na Geografia Árabe» in Arqueologia Medieval 9, Mértola-Porto, 2005, pp. 61-75.

RODRIGUEZ, R. et SOUTO J., «Glyptographie et numismatique omeyyades: évidences de relations en Al-Andalus?» in Actes du XVIe colloque International de Glyptographie de Münsterschwarzach, (du 12 au 18 juillet 2008), Braine le Château, 2009, pp. 207-234.

ROSENBERGER, B., «Ports Médiévaux de la côte Mediterranéenne du Maroc. Guerre et commerce» in Arqueologia Medieval 9, Mértola-Porto, 2005, pp. 21-40.

ROSSELÓ BORDOY, G., «L'Islam a les Illes Balears», Palma de Majorque, 1968; idem, «Terminología naval según las fuentes históricas y lexicográficas» in Naves Andalusies en Cerámicas Mallorquinas, Palma de Majorque, 1993, pp. 29-67.

RUSKA, J. (PLESSNER, M.), «'Anbar», Enclycopédie de l'Islam 2, t I, pp. 498-9.

SIDARUS, A. et REI, A., «Lisboa e seu termo segundo os geografos arabes», in Arqueologia Medieval, 7, Mértola-Porto, 2001, pp.37-72.

SILVA TAVARES, C. da et COELHO-SOARES, A., 1987, «Escavações arqueológicas no Creiro (Arrábida), Campanha de 1987» in Setúbal Arqueológica 8, Setubal, pp. 228-237.

SOUTO, J., « Marcas de cantero, graffiti y 'signos magicos' en el Mundo Islamico: panoramiqua general», in Actes du Ve colloque International de glyptographie, I, Pontevedra, 1988, pp. 463-486; idem, «Glyptographie omeyyade: signes lapidaires à la Grande Mosquée de Cordoue. Documentation de noms propres», in Actes du XIIe Colloque International de Glyptographie de Saint Christophe en Brionnais, (du 10 au 15 juillet 2000), Braine le Château, 2001, pp. 283-307.

TAVARES da SILVA, C. et alii., «Escavaçōes arqueológicas no Castelo de Alcácer do Sal (campanha de 1979)», in Setúbal Arqueológica, 1980, vol. 6-7, Setúbal, 1980-81, pp. 114-218.

Conimbriga, 49 (2010) 183-224 
TERRASSE, H., «Caractères généraux des émirats espagnols du XIe siècle», in Revue de l'Occident musulman et de la Méditerranée, $\mathrm{n}^{\circ}$ 2, Aix en Provence, 1966, pp. 189-198.

TERRON ALBARRÁN, M., Extremadura Musulmana, Badajoz, 1991.

VAN BELLE, J.L., «Les signes lapidaires: essai de terminologie», Actes du Colloque International de Glyptographie de Saragosse, Braine le Château, 1983; idem 2001, «Signes gravés, signes écrits, signes reproduits», in Signo, Revista de Historia de la Cultura Escrita 8, 1983.

VARELA GOMES, R. et VARELA GOMES, M., «Palácio Almóada da Alcáçova de Silves» in Catálogo da exposição no Museu Nacional de Arqueologia, Lisbonne, 2001; idem, "Ambiente natural e complexo edificado Ribāt da Arrifana» in Cultura Material e Espiritualidade, Silves, 2007, pp. 51-64; idem, «Quotidiano, Religião e Guerra Santa Ribāt da Arrifana» in Cultura Material e Espiritualidade, Silves, 2007, pp. 65-81.

VIGUERA MOLINS, M. J., «Historiografia» in $\mathrm{M}^{\mathrm{a}} \mathrm{J}$. Viguera, coord., El retroceso territorial de al-Andalus. Almorávides y Almohades. Siglos XI al XIII. Vol. VIII/*** de Historia de España, dir. Ramón Menéndez Pidal, Madrid, 1997, pp. 3-37; idem, «Historia Politica» in Viguera, $\mathrm{M}^{\mathrm{a}} \mathrm{J}$. (coord), El retroceso territorial de al-Andalus. Almorávides y Almohades. Siglos XI al XIII. Vol. VIII/** de Historia de España, dir. Ramón Menéndez Pidal, Madrid, 1997, pp. 41-123.

Conimbriga, 49 (2010) 183-224 


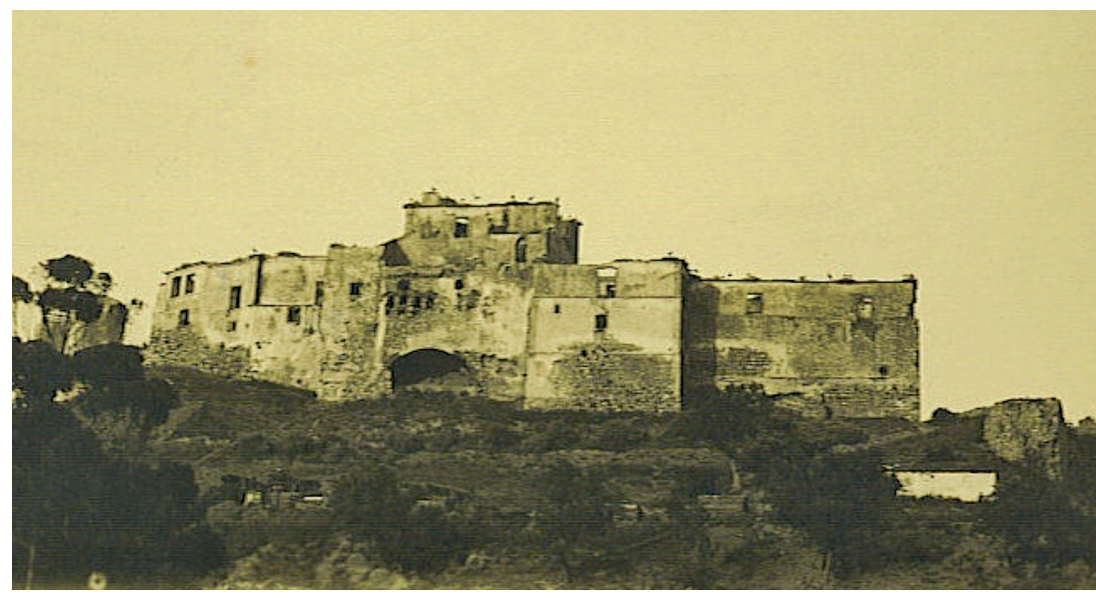

FIG. 1. Bilhete postal com imagem do Castelo de Alcácer do Sal em finais do século XIX. (Arquivo Municipal de Alcácer do Sal).

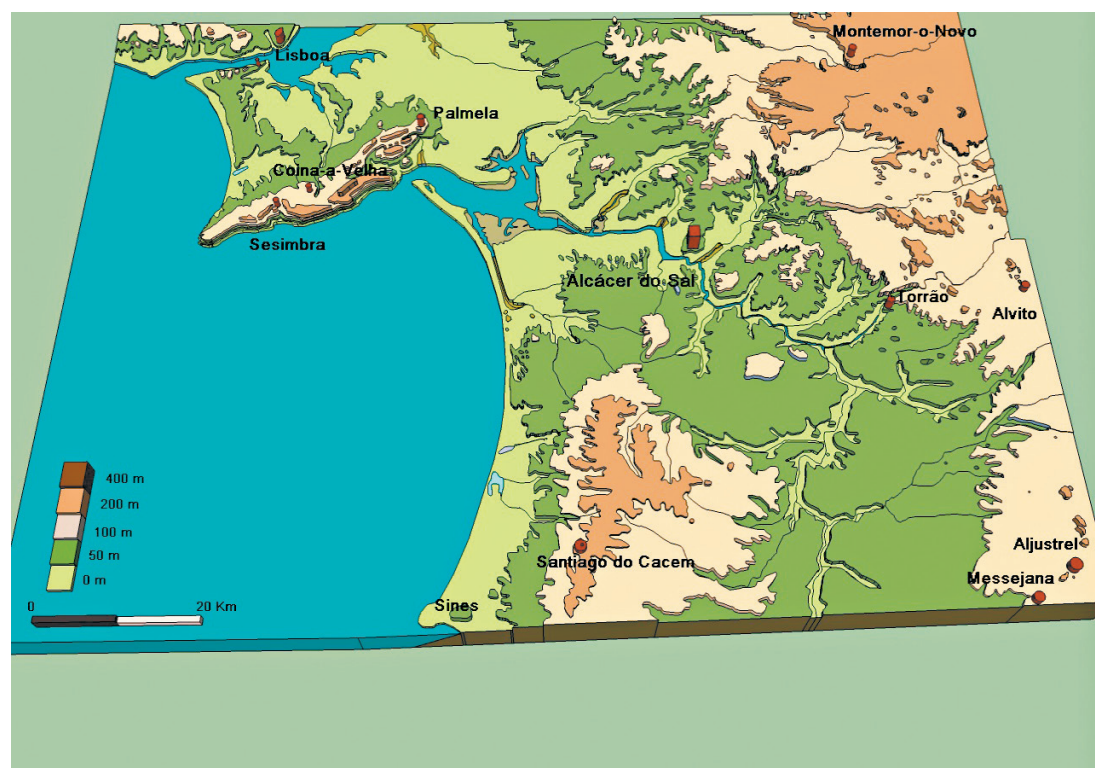

FIG. 2. Localização geo-morfológica de Alcácer do Sal 


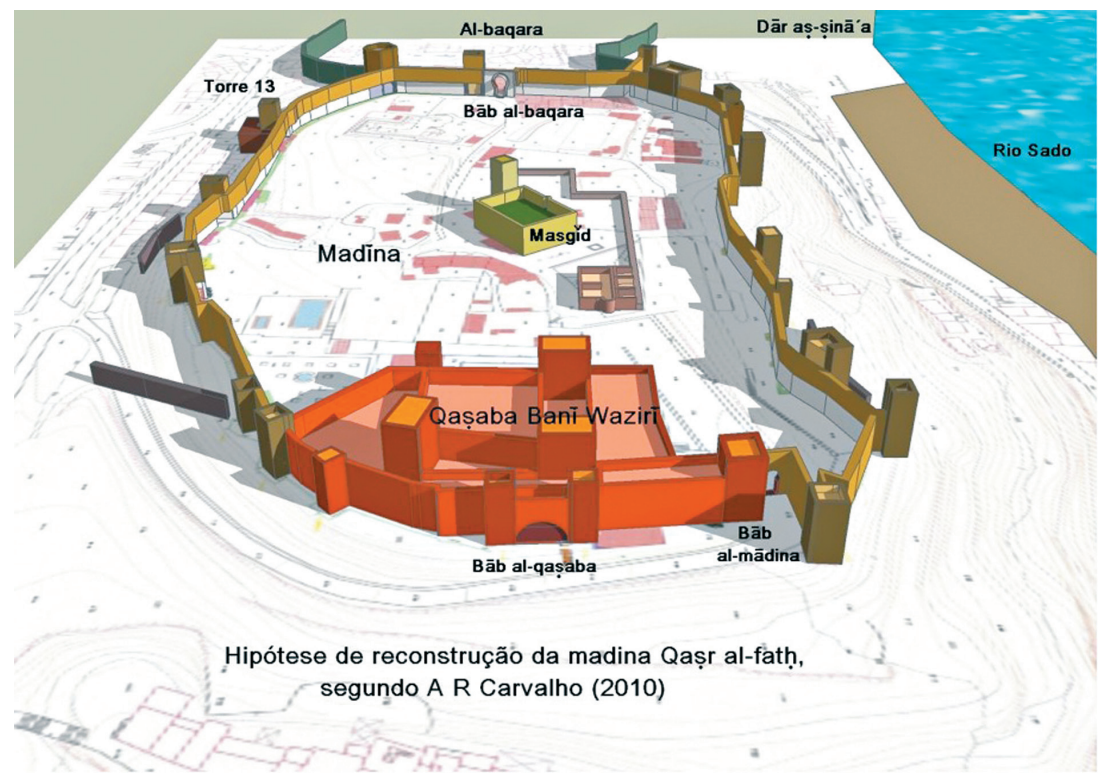

FIG. 3. Reconstrução de madīna Qașr al-Fath 
Qaṣr al Fatḥ/ Alcácer do Sal

Torre dos Grafitos - Torre 13

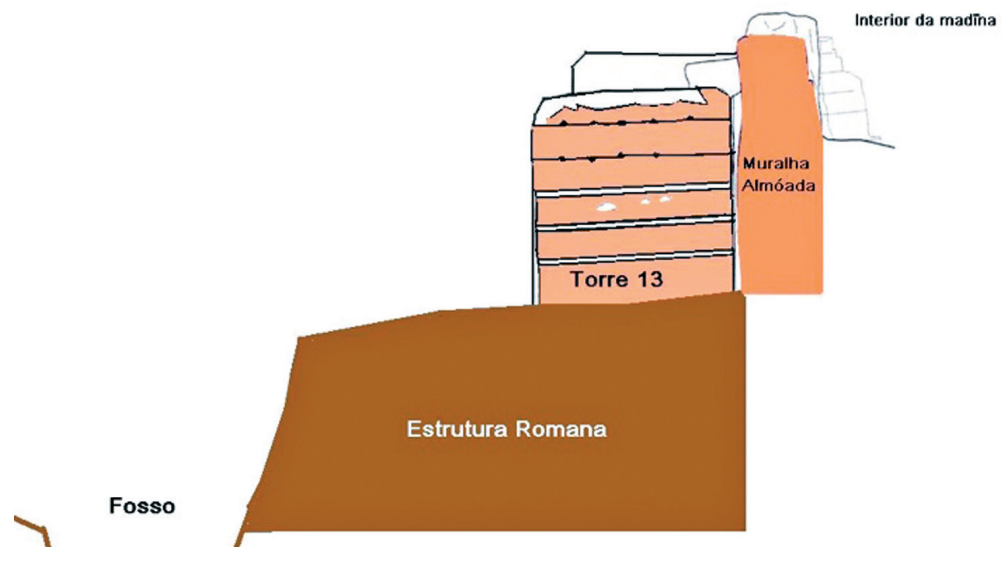

FIg. 4. Perfil da torre 13

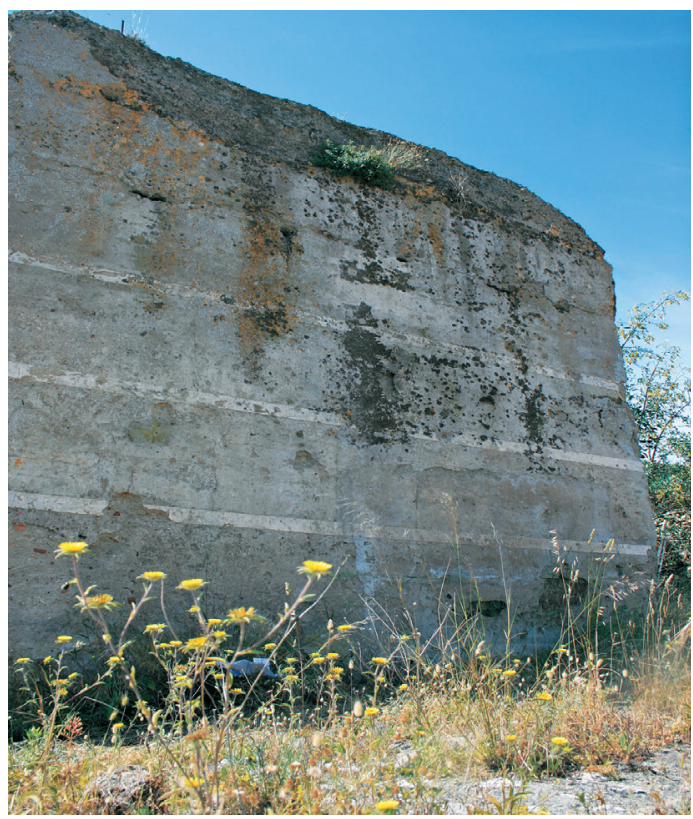

FIG. 5. Fachada norte da Torre 13 

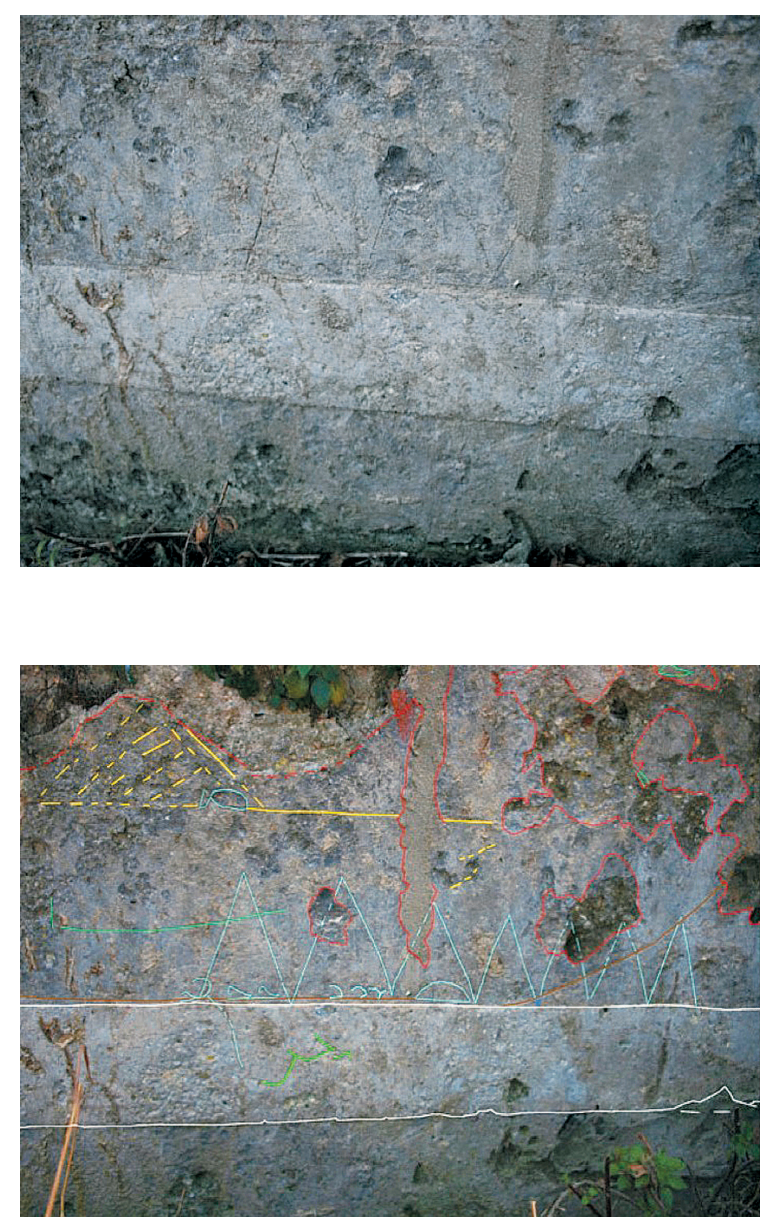

FIG. 6 e 7. O grande barco realçado na fotografia

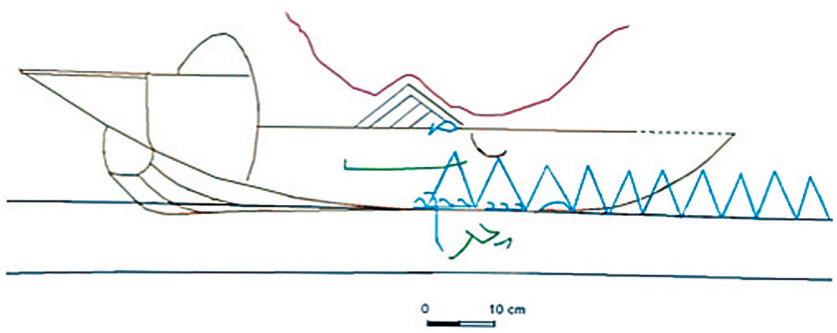

FIG. 8. Grafito do grande barco 

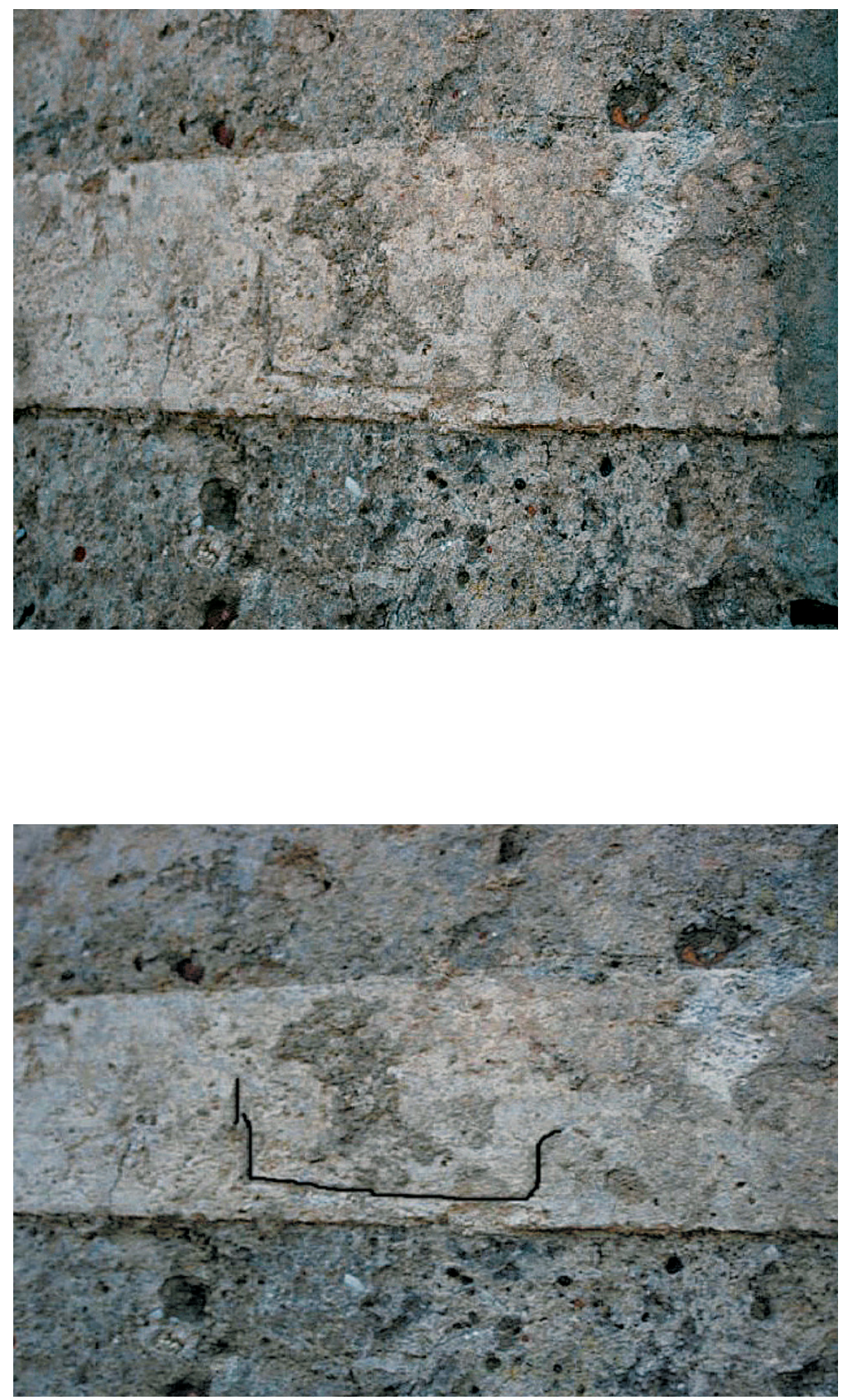

Fig. 9 e 10. Grafito de um barco de pesca e os seus contornos sobre a fotografia 


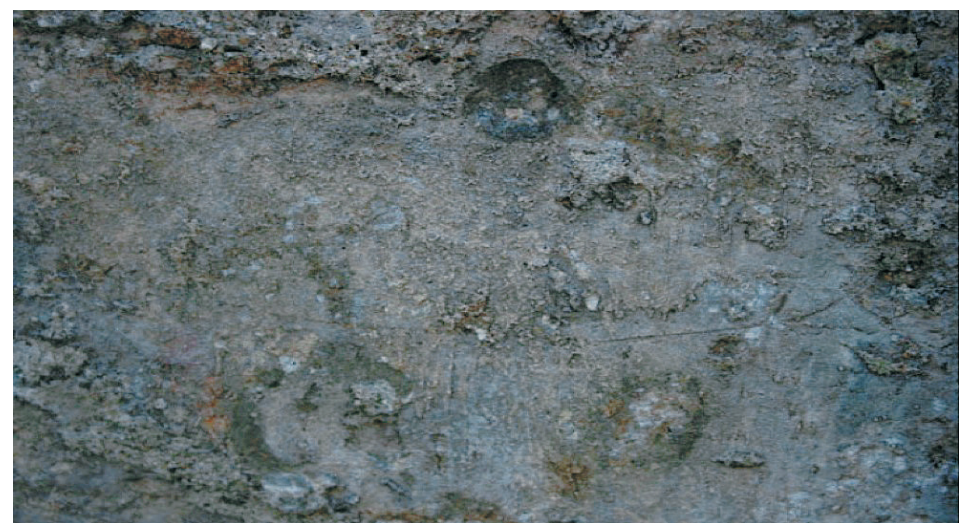

FIG. 11. Barco com os tridentes
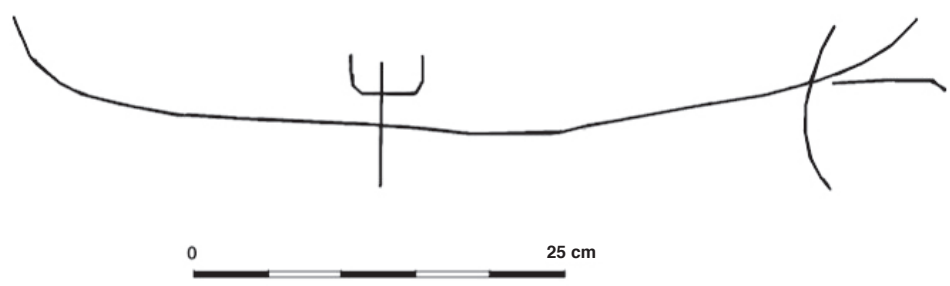

FIG. 12. Desenho do barco com o(s) tridente(s)

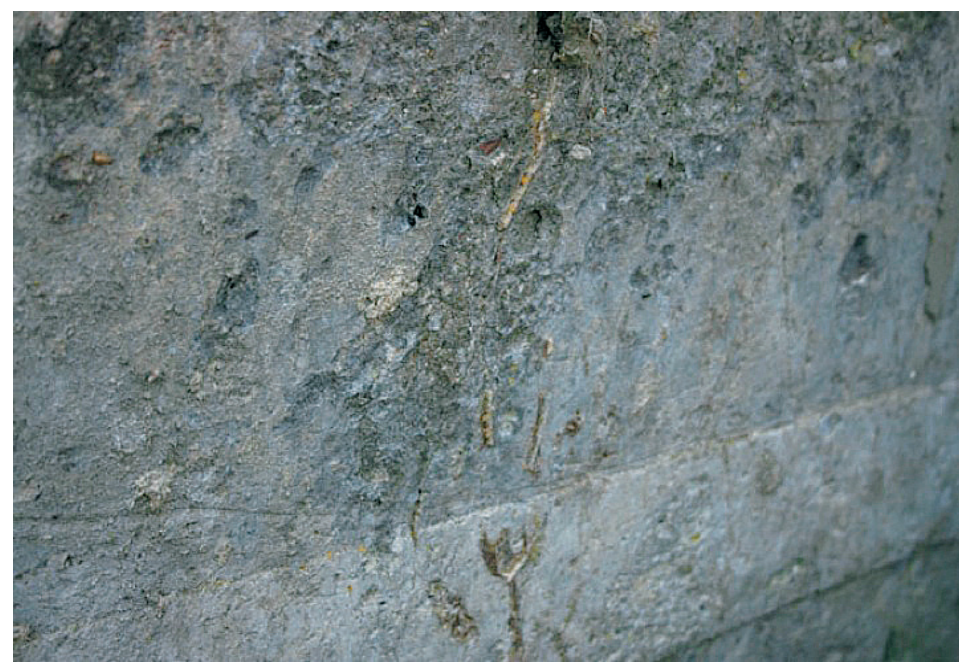

FIG. 13. O tridente "aureolado" 

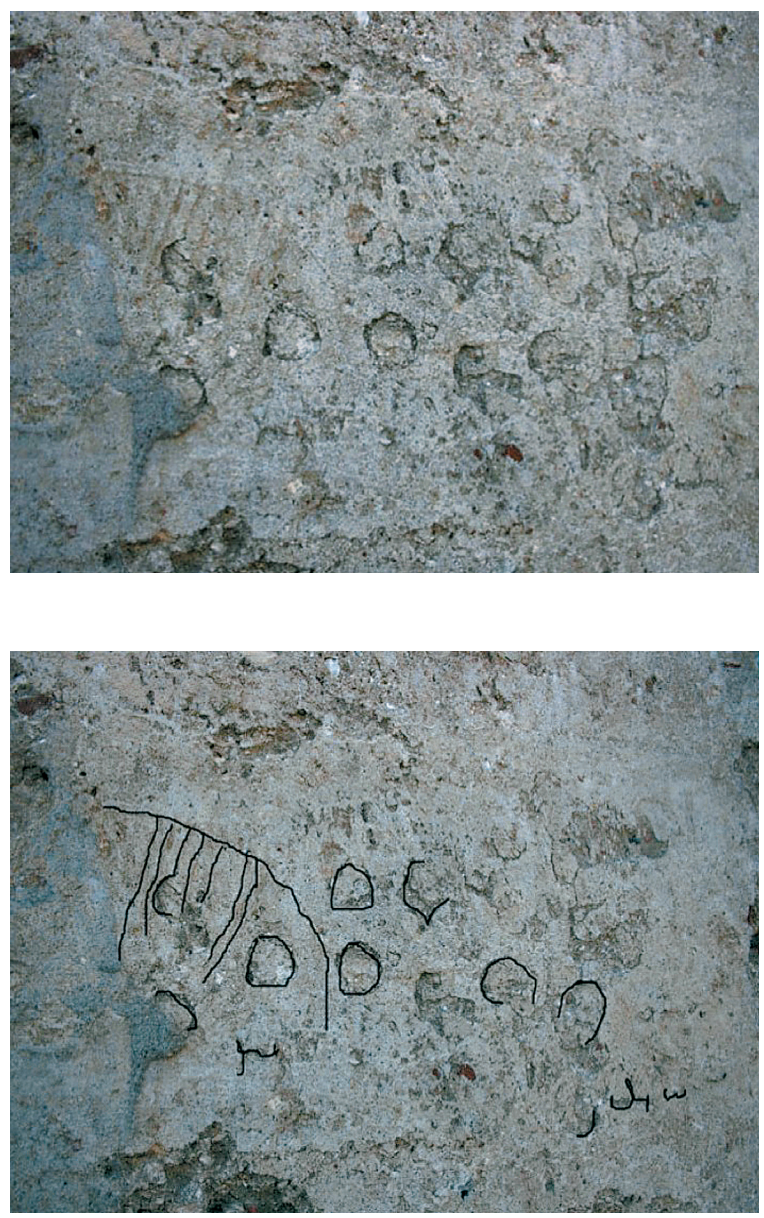

FIG. 14 e 15. Grafito do cachalote com âmbar que sai da sua boca e os traços realçados na fotografia

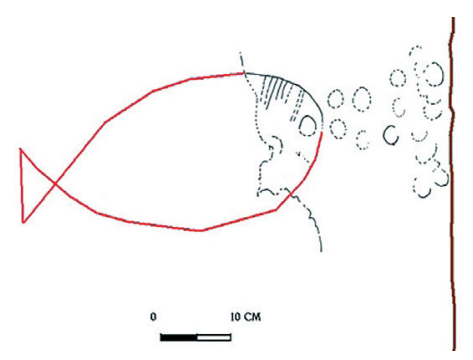

FIG. 16. Desenho do cachalote 


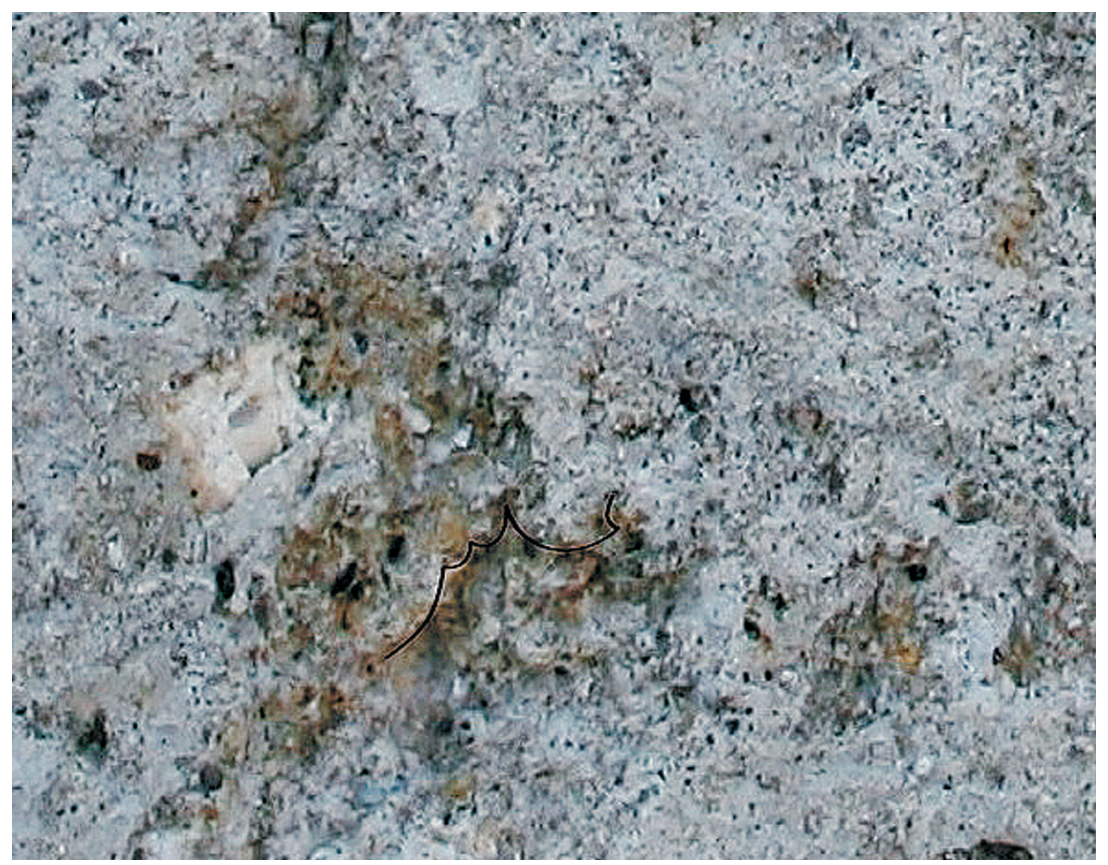

FIG. 17. A inscrição 'anbar / âmbar.

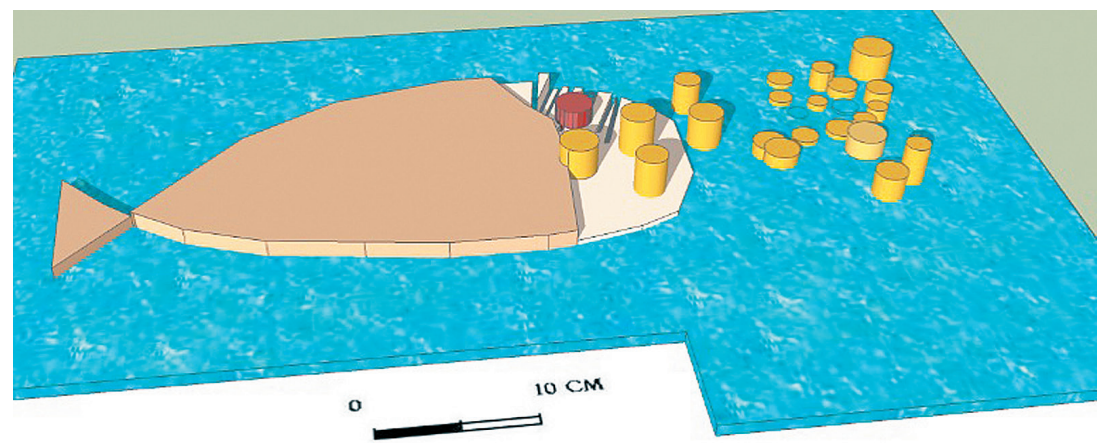

FIG. 18. Reconstrução $3 D$ do cachalote expelindo o âmbar, tal como está representado no grafito - ARC 

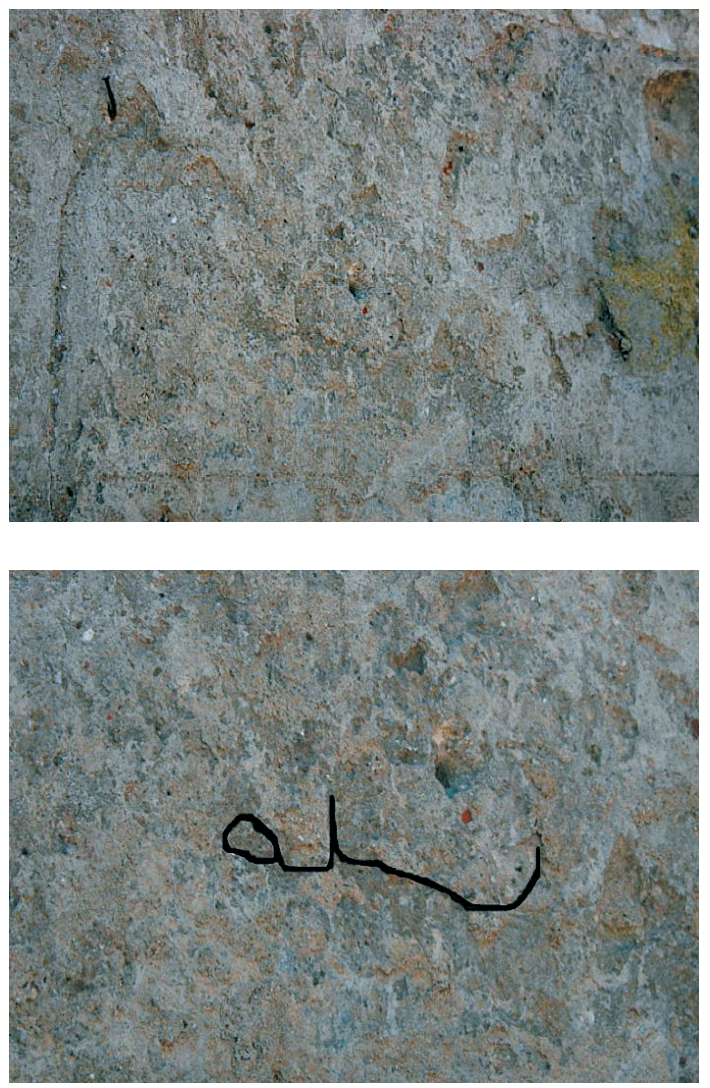

FIG. 19 e 20. O nome de Allāh (?) ou a contração da expressão "b-ismi-llāh" e o seu realce sobre a fotografia

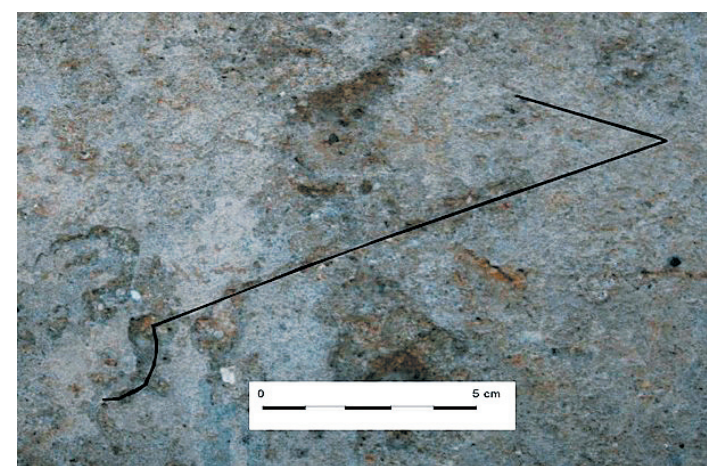

FIG. 21. Desenho sobre a fotografia do nome Hasan 


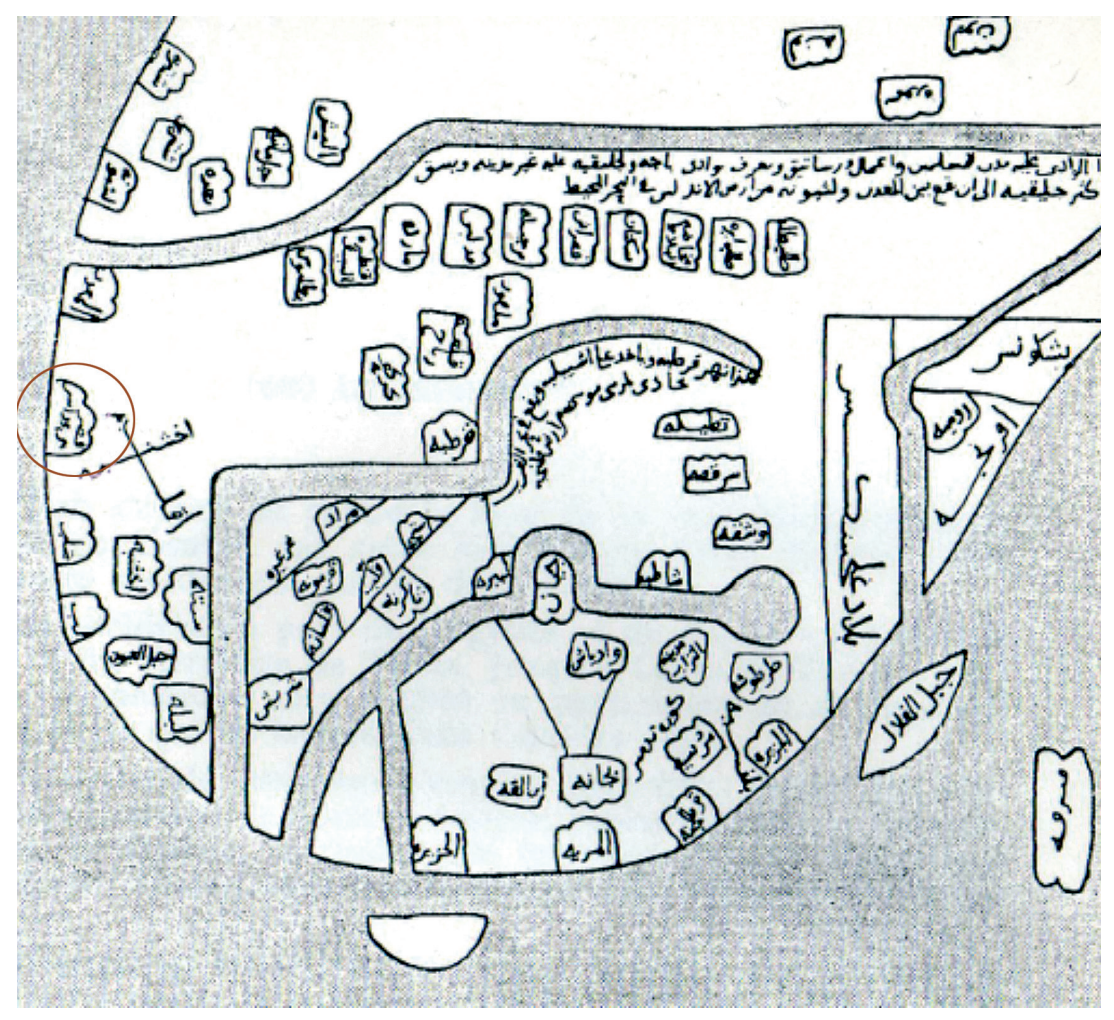

FIG. 22. O mapa do al-Andalus de Ibn Hawqal

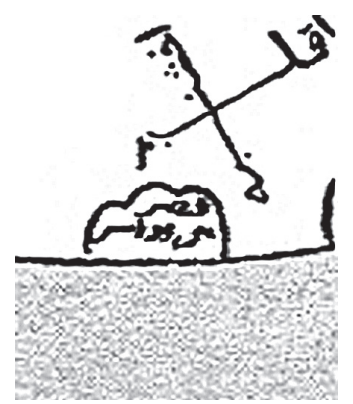

FIG. 23. Pormenor aumentado do mapa de Ibn Hawqal, com o nome de Qasr Bani Warras 